\title{
Angiotensin II Inhibits Insulin Signaling in Aortic Smooth Muscle Cells at Multiple Levels

\author{
A Potential Role for Serine Phosphorylation in Insulin/Angiotensin II Crosstalk
}

\author{
Franco Folli, ${ }^{\star \ddagger}$ C. Ronald Kahn, ${ }^{\ddagger}$ Hans Hansen, ${ }^{\ddagger}$ Julie L. Bouchie, ${ }^{\ddagger}$ and Edward P. Feener ${ }^{\ddagger}$ \\ ${ }^{*}$ Department of Medicine I and Unitá di Malattie Metaboliche, I.R.C.C.S.H. San Raffaele, 20132 Milano, Italy; and ${ }^{\ddagger}$ Research Division, \\ Joslin Diabetes Center, Harvard Medical School, Boston, Massachusetts 02215
}

\begin{abstract}
To investigate potential interactions between angiotensin II (AII) and the insulin signaling system in the vasculature, insulin and AII regulation of insulin receptor substrate-1 (IRS-1) phosphorylation and phosphatidylinositol (PI) 3-kinase activation were examined in rat aortic smooth muscle cells. Pretreatment of cells with AII inhibited insulin-stimulated PI 3-kinase activity associated with IRS-1 by $60 \%$. While AII did not impair insulin-stimulated tyrosine phosphorylation of the insulin receptor (IR) $\beta$-subunit, it decreased insulin-stimulated tyrosine phosphorylation of IRS-1 by 50\%. AII inhibited the insulin-stimulated association between IRS-1 and the p85 subunit of PI 3-kinase by $30-50 \%$ in a dose-dependent manner. This inhibitory effect of AII on IRS-1/PI 3-kinase association was blocked by the AII receptor antagonist saralasin, but not by $\mathrm{AT}_{1}$ antagonist losartan or $\mathrm{AT}_{2}$ antagonist PD123319. AII increased the serine phosphorylation of both the IR $\beta$-subunit and IRS-1. In vitro binding experiments showed that autophosphorylation increased IR binding to IRS-1 from control cells by 2.5 fold versus 1.2-fold for IRS-1 from AII-stimulated cells, suggesting that AII stimulation reduces IRS-1's ability to associate with activated IR. In addition, AII increased p85 serine phosphorylation, inhibited the total pool of p85 associated PI 3-kinase activity, and decreased levels of the p50/ p55 regulatory subunit of PI 3-kinase. These results suggest that activation of the renin-angiotensin system may lead to insulin resistance in the vasculature. (J. Clin. Invest. 1997. 100:2158-2169.) Key words: angiotensin II • insulin receptor substrate-1 • phosphatidylinositol 3-kinase $\bullet$ vascular smooth muscle cells • insulin resistance
\end{abstract}

\section{Introduction}

Angiotensin II (AII) ${ }^{1}$ is the main effector peptide of the reninangiotensin system (RAS) and plays an important role in the regulation of vascular homeostasis $(1,2)$. Increased AII action

Address correspondence to Edward P. Feener, Ph.D., Research Division, Joslin Diabetes Center, One Joslin Place, Boston, MA 02215. Phone: 617-732-2599; FAX: 617-732-2637; E-mail: feenere@joslab. harvard.edu

Received for publication 22 January 1997 and accepted in revised form 28 August 1997.

J. Clin. Invest.

(C) The American Society for Clinical Investigation, Inc. 0021-9738/97/11/2158/12 \$2.00

Volume 100, Number 9, November 1997, 2158-2169

http://www.jci.org in the vasculature via its local induction within the vascular wall (3-5) has been strongly implicated in the pathogenesis of macrovascular disease by, for example, stimulating neointimal thickening and altering vascular gene expression (6-9). Beneficial effects of angiotensin converting enzyme (ACE) inhibition on cardiovascular disease has been reported in many (for review see reference 10) but not all (11) clinical trials. Recent reports have also shown that inhibition of the RAS can increase insulin sensitivity (12-14), suggesting a role for the RAS in the regulation of insulin action. As hypertension and insulin resistance often coexist and are leading risk factors for cardiovascular disease (15-18), interactions between AII and insulin signaling systems may have an important role in the regulation of vascular physiology and the development of atherosclerosis.

While several isoforms of the AII receptor have been described, the predominant isoform expressed in macrovascular smooth muscle cells is the $\mathrm{AT}_{1}$ receptor $(2,19)$. This receptor is $\mathrm{G}$ protein-coupled to a variety of intercellular signaling pathways, including the phospholipase $\mathrm{C}$ /protein kinase $\mathrm{C}$ (PKC) pathway, cytosolic calcium, and tyrosine kinases including JAK and FAK (2, 20-22). In addition to its direct ability to regulate growth, migration and gene expression in vascular cells (2325), AII may exhibit additional actions in vivo by modulating the signaling of other hormones. Crosstalk between G protein-coupled receptors and cell surface tyrosine kinase receptors $(26,27)$ may provide a mechanism for such indirect actions of AII on vascular cell physiology. Recently, in in vivo studies we have shown that AII infused into the heart can both stimulate insulin receptor substrate-1 and -2 (IRS-1, -2) tyrosine phosphorylation and inhibit PI 3-kinase activity associated with IRS proteins $(28,29)$.

The insulin receptor is a heterotetrameric tyrosine kinase and after insulin binding undergoes a rapid tyrosine autophosphorylation that both activates the receptor kinase and allows transient interaction with intracellular protein substrates including IRS-1 and -2 via their phosphotyrosine binding domains (PTB domains) (30-33). This allows tyrosine phosphorylation of IRS-1 and IRS-2 on YMXM/YXXM motifs that induces their binding to Src homology 2-domain (SH-2) containing molecules, including phosphatidylinositol 3-kinase (PI 3-kinase), Grb2, SHPTP2, NCK, and Fyn (30, 32, 34, 35). The interaction between the IRS proteins and PI 3-kinase occurs through the $\mathrm{p} 85$ regulatory subunit of the enzyme resulting in an increase in catalytic activity of the p110 subunit $(34,36,37)$. While alterations in insulin action in the vasculature, mediated via both the insulin and IGF-1 receptors, have been proposed

1. Abbreviations used in this paper: AII, angiotensin II; IRS, insulin receptor substrate; HIR, human insulin receptor; PI, phosphatidylinositol; PKC, protein kinase C; RASMC, rat aortic smooth muscle cells; WGA, wheat germ agglutinin. 
to contribute to atherosclerosis and the regulation of vascular tone $(38,39)$, little is known regarding the pathways of insulin signaling, and their regulation, in vascular cells.

In this report, we have used cultured rat aortic smooth muscle cells (RASMC) as a model to examine the potential effects of AII on insulin signaling to IRS-1 and PI 3-kinase in macrovascular cells. We show that AII impairs insulin stimulation of IRS-1 tyrosine phosphorylation and coupling of the insulin receptor pathway to PI 3-kinase. These studies suggest that activation of the RAS may contribute to insulin resistance in AII-responsive tissues such as the vasculature.

\section{Methods}

Cell culture. RASMC were isolated from Sprague-Dawley rats as described previously (23), cultured in Dulbecco's minimal essential medium (DMEM) containing 10\% FCS, and used between passage 7 and 13. Confluent monolayers of cells were serum deprived in DMEM containing $0.1 \%$ (wt/vol) bovine serum albumin (BSA) for $18 \mathrm{~h}$ before the experiment. Cells were stimulated with $100 \mathrm{nM}$ AII, insulin, or insulin-like growth factor-1 (IGF-1), $25 \mathrm{ng} / \mathrm{ml}$ platelet-derived growth factor (PDGF), or $160 \mathrm{nM}$ phorbol 12-myristate 13-acetate (PMA) (Sigma Chemical Co., St. Louis, MO; Boehringer Mannheim Biochemicals, Indianapolis, IN; UBI, Lake Placid, NY). AII receptor antagonist studies were performed on cells that were pretreated for 15 min with $1 \mu$ M Sar ${ }^{1}$, Ile $^{8}$-angiotensin (Sigma Chemical Co.), losartan (provided by Dr. Ronald D. Smith, DuPont Merck Pharmaceutical Co., Wilmington, DE), or PD123319 (provided by Dr. D.G. Taylor, Parke-Davis, Ann Arbor, MI) followed by stimulation with AII and/or insulin. The effects of PI 3-kinase inhibition were examined in cells pretreated with $50 \mu \mathrm{M}$ LY294002 (BioMol) for $15 \mathrm{~min}$

PI 3-kinase assay. Confluent 10-cm dishes of serum-deprived RASMC were stimulated for 7 min with $100 \mathrm{nM}$ AII, 5 min with $100 \mathrm{nM}$ insulin, or for 2 min with AII followed by an additional 5 min with insulin. Cells were then washed twice with ice-cold PBS containing $2 \mathrm{mM}$ $\mathrm{Na}_{2} \mathrm{VO}_{4}$ and lysed in ice-cold freshly prepared lysis buffer containing $50 \mathrm{mM}$ Hepes, pH 7.4, $137 \mathrm{mM} \mathrm{NaCl}, 1 \mathrm{mM} \mathrm{MgCl}, 1 \mathrm{mM} \mathrm{CaCl}_{2}, 2 \mathrm{mM}$ $\mathrm{Na}_{2} \mathrm{VO}_{4}, 10 \mathrm{mM}$ sodium pyrophosphate, $100 \mathrm{mM}$ sodium fluoride, $2 \mathrm{mM}$ EDTA, $2 \mathrm{mM}$ phenylmethylsulfonylfluoride, $10 \mu \mathrm{g} / \mathrm{ml}$ aprotinin, 10 $\mu \mathrm{g} / \mathrm{ml}$ leupeptin, $10 \mathrm{mM}$ benzamidine, $10 \%$ (vol/vol) glycerol, and $1 \%$ (vol $/ \mathrm{vol}$ ) Triton X-100 for $1 \mathrm{~h}$. Insoluble material was removed by centrifugation for $15 \mathrm{~min}$ at $12,000 \mathrm{rpm}$ at $4^{\circ} \mathrm{C}$. $1-\mathrm{ml}$ aliquots of supernatants, normalized to protein, were incubated overnight at $4^{\circ} \mathrm{C}$ with rabbit polyclonal antibodies against IRS-1 (29), p85 subunit of PI 3-kinase, and PDGF receptor (UBI) and the immunocomplexes were precipitated with a $50 \%$ solution of protein A-Sepharose $6 \mathrm{MB}$ (Pharmacia Biotech AB, Uppsala, Sweden). In vitro PI 3-kinase assays were performed as described previously (34). The ${ }^{32} \mathrm{P}$-labeled 3-P-phosphatidylinositol was visualized using a PhosphorImager and normalized using IMAGEQUANT software (Molecular Dynamics, Sunnyvale, CA).

Immunoprecipitation and Western blotting. Immunoprecipitations of cell lysates, normalized to protein, were performed overnight at $4^{\circ} \mathrm{C}$. Tyrosine phosphorylation of immunoprecipitated IRS- 1 and IR was detected by Western blotting using antiphosphotyrosine antibody (4G10) followed by rabbit anti-mouse IgG (DAKO Corp., Carpenteria, CA) and ${ }^{125}$ I-protein A (Amersham Corp., Arlington Heights, IL), as described previously $(29,34)$. Western blotting was performed using antibodies against $\mathrm{p} 85$ (UBI) and $\mathrm{p} 110 \alpha$ or IR $\beta$-subunit (Santa Cruz Biotechnology, Santa Cruz, CA) followed by ${ }^{125}$ I-protein-A.

In vivo phosphorylation. Confluent monolayers of RASMC in 15-cm plates were serum-starved for $18 \mathrm{~h}$ and then incubated for $4 \mathrm{~h}$ in phosphate-free Eagle's MEM (GIBCO BRL, Gaithersburg, MD)

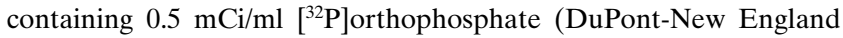
Nuclear, Boston, MA). Cells were then stimulated as described above. Labeling was terminated with liquid $\mathrm{N}_{2}$ and cells were thawed in lysis buffer and scraped from the dish. Insoluble material was removed by centrifugation for $15 \mathrm{~min}$ at $12,000 \mathrm{rpm}$ at $4^{\circ} \mathrm{C}$. Supernatants were incubated overnight at $4^{\circ} \mathrm{C}$ with antibodies directed against IRS-1 or p85 subunit of PI 3-kinase and the immunocomplexes were precipitated with a $50 \%$ solution of protein A-Sepharose. For in vivo phosphorylation studies of the insulin receptor, cell lysates were centrifuged at $100,000 \mathrm{~g}$ for $30 \mathrm{~min}$, the soluble fraction was applied to a wheat germ agglutinin-Sepharose column (Sigma Chemical Co.) and eluted with $0.3 \mathrm{M} \mathrm{N}$-acetyl-D-glucosamine (Sigma Chemical Co.). The insulin receptor enriched eluates were incubated with $20 \mu \mathrm{g}$ of polyclonal anti-insulin receptor antibodies (Santa Cruz Biotechnology) and the immunocomplexes were precipitated with a $50 \%$ solution of protein A-Sepharose 6MB. The washed immunocomplexes were eluted with Laemmli sample buffer and separated on 6\% SDSPAGE for the IRS-1 protein and $7.5 \%$ SDS-PAGE for the insulin receptor $\beta$-subunit and p85 regulatory subunit of PI 3-kinase. Proteins were transferred to nitrocellulose paper $(0.2 \mu \mathrm{m}$ pore size, Schleicher \& Schuell Inc., Keene, NH) and visualized by autoradiography. The ${ }^{32} \mathrm{P}$-labeled protein bands were quantitated using IMAGEQUANT software of the PhosphorImager.

Phosphoamino acid analysis. The nitrocellulose containing ${ }^{32} \mathrm{P}-$ labeled IRS-1, p85 and $\beta$-subunit was excised and treated with $0.5 \%$ (wt/vol) PVP-40 (Sigma Chemical Co.) in $100 \mathrm{mM}$ acetic acid for 30 min at $37^{\circ} \mathrm{C}$. The paper was then washed five times with water and digested with $10 \mu \mathrm{g}$ of TPCK-trypsin (Worthington Biochemical Corp., Freehold, NJ) in $\mathrm{NaHCO}_{3}(\mathrm{pH} 8.2)$ containing $5 \%$ acetonitrile at $37^{\circ} \mathrm{C}$ for $24 \mathrm{~h}$. An additional $10 \mu \mathrm{g}$ of TPCK-trypsin was added, and the digestion was continued for $24 \mathrm{~h}$. This technique consistently eluted $90-95 \%$ of the phosphopeptides. The peptides were then evaporated in a Speed Vac, partially hydrolyzed in $100 \mu \mathrm{l}$ of $6 \mathrm{~N} \mathrm{HCl}$ at $110^{\circ} \mathrm{C}$ for $2 \mathrm{~h}$, diluted in $1 \mathrm{ml}$ of water and dried. Phosphoamino acid analysis was performed by electrophoresis on cellulose thin layer plates as described previously (40).

In vitro insulin receptor/IRS binding. Control or AII-stimulated (100 $\mathrm{nM}, 7 \mathrm{~min}$ ) RASMC were harvested in ice-cold lysis buffer and fractionated in a column using wheat germ agglutinin (WGA) Sepharose. The fraction eluted with $0.3 \mathrm{mM} \mathrm{N}$-acetyl-glucosamine (NAGA) was autophosphorylated in vitro for $30 \mathrm{~min}$ (40) and allowed to interact with a glutathione S-transferase fusion protein containing the PTB domain of IRS-1 (GST-IRS-1-PTB) (kindly provided by Dr. S. Shoelson, Joslin Diabetes Center, Boston, MA). After a 2-h incubation the samples were precipitated using glutathione Sepharose 4B (Pharmacia Biotech), separated by SDS-PAGE, and the insulin receptor associated with the GST-IRS-1-PTB was quantitated by immunoblotting using an antibody against the $\beta$-subunit of the insulin receptor. The flow through from the WGA column was immunoprecipitated with anti-IRS-1 antibody and protein A-Agarose. Immunoprecipitates were washed three times and divided into two equal aliquots. WGA purified human insulin receptor (HIR) was isolated from Chinese hamster ovary cells expressing HIR (CHO-HIRc). Equal aliquots of HIR, autophosphorylated for $30 \mathrm{~min}$ at $22^{\circ} \mathrm{C}$ as described previously (40) or used in its basal phosphorylation state, were incubated with IRS- 1 immunoprecipitates for $2 \mathrm{~h}$ at $4^{\circ} \mathrm{C}$ and washed once, as described by Wolf et al. (41). Immunoprecipitates were separated by SDS-PAGE and immunoblotted with antibody against the $\beta$-subunit of the insulin receptor followed by ${ }^{125}$ I-protein A.

Statistics. Comparison of data presented as mean \pm SEM was performed using the one way ANOVA or the unpaired Student's $t$ test as indicated. Values of $P<0.05$ were considered significantly different.

\section{Results}

Effects of AII, insulin, and IGF-1 on IRS-1-associated PI 3-kinase activity, insulin receptor and IRS-1 tyrosine phosphorylation, and IRS-1/PI 3-kinase docking. The tyrosyl-phosphorylation of IRS-1 is necessary for its binding to $\mathrm{SH} 2$ domains of the p85 regulatory subunit of PI 3-kinase and its 
activation of the PI 3-kinase enzymatic activity $(34,36,37)$. To investigate the interactions between AII and insulin on the IRS-1 signaling pathway in RASMC, cells were stimulated for 5 min with $100 \mathrm{nM}$ insulin in the absence or presence of a 2 min preincubation with $100 \mathrm{nM}$ AII. PI 3-kinase activity associated with IRS-1 precipitates was measured using an in vitro assay, and results from a typical experiment are shown in Fig. 1 $A$. A low level of IRS-1-associated PI 3-kinase activity was present in the basal state and this was stimulated by insulin fivefold ( $P<0.05$, ANOVA). Pretreatment of cells with AII caused a small, nonsignificant decrease in basal IRS-1 associated PI 3-kinase activity and decreased insulin stimulated IRS-1 associated PI $3-$ kinase activity by $60 \%(P<0.05$, Fig. $1 B)$. A time-course study of the AII effect demonstrated that simultaneous addition of AII and insulin, or the addition of AII 2 min after insulin, also reduced insulin stimulation of PI 3-kinase activity, although to a lesser extent (data not shown). A significant IGF-1 stimulation of IRS-1 associated PI 3-kinase activity compared with control $(P<0.05$, ANOVA) was also inhibited by AII (Fig. $1 C$ ), indicating that AII's effect was not unique to the insulin receptor.

To investigate the potential mechanisms responsible for the AII-induced decrease in insulin-stimulated PI 3-kinase associated with IRS-1, effects of AII on insulin receptor and IRS-1 tyrosine phosphorylation and IRS-1/p85 docking were examined. RASMC were stimulated with AII and/or insulin as described above, insulin receptor was immunoprecipitated from WGA purified cell lysates, and tyrosine phosphorylation of the insulin receptor $\beta$-subunit was assessed by immunoblotting using antiphosphotyrosine antibodies. Insulin stimulated a fivefold increase $(P<0.05)$ in tyrosine phosphorylation of the insulin receptor in these cells (Fig. $2 A$ ). Immunoprecipitation of cell extracts with anti-IRS-1 antibodies followed by Western blotting with antiphosphotyrosine antibodies revealed that insulin also stimulated a fivefold increase in IRS-1 tyrosine phosphorylation (Fig. 2 B). AII (100 nM) did not significantly alter tyrosine phosphorylation of the insulin receptor in either the absence or presence of insulin (Fig. $2 A$ ). AII alone also had no effect on basal IRS-1 tyrosine phosphorylation, but AII pretreatment did inhibit insulin stimulated IRS-1 phosphorylation by $50 \%$ (Fig. 2 B). The AII-induced decrease in insulinstimulated tyrosine phosphorylation of IRS-1 was accompanied by a parallel decrease in p85 binding to IRS-1 (Fig. $2 C$ ). The level of IRS-1/p85 association in the presence of AII and insulin was significantly reduced compared with insulin stimulation alone $(P<0.05)$ and was not significantly different than that in the basal state or in the presence of AII alone. The inhibition of insulin-stimulated IRS-1/p85 association by AII occurred in a dose-dependent manner (Fig. $3 A$ ) and significant inhibition of insulin-stimulated IRS-1/p85 docking was observed in cells pretreated with $0.1 \mathrm{nM}$ AII, suggesting that this modulatory effect of AII on insulin signaling occurs at physiological levels.

In order to determine if this AII effect on insulin stimulated IRS-1/PI 3-kinase association was a receptor mediated phenomenon, cells were preincubated with AII receptor

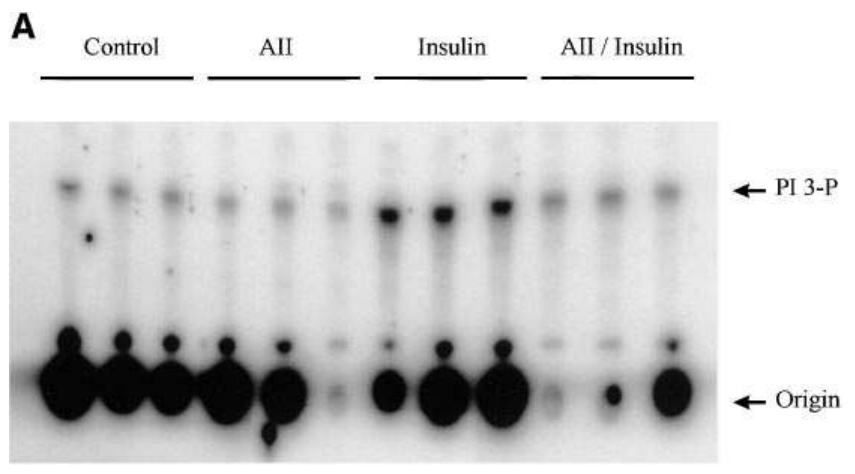

C

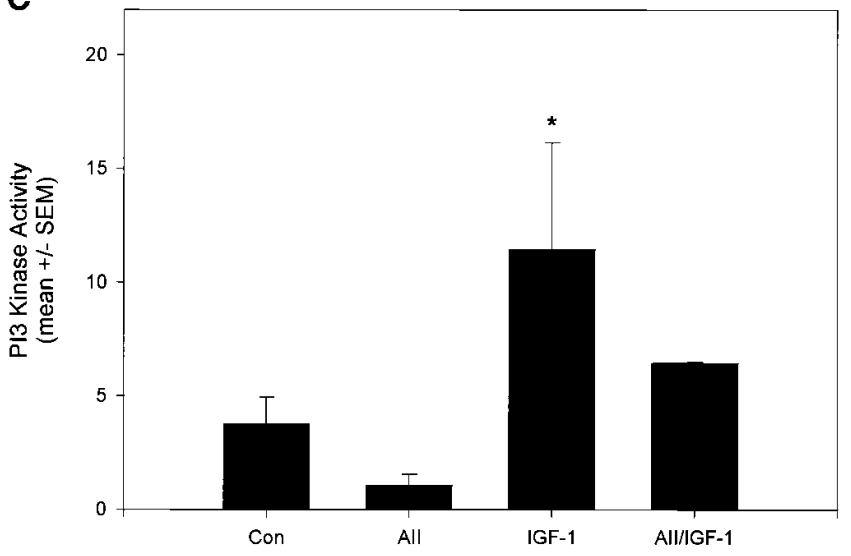

B

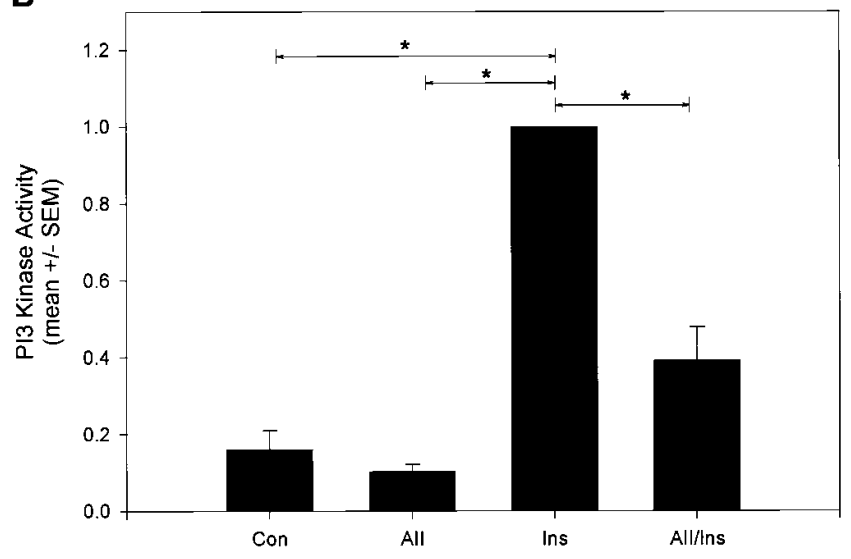

Figure 1. Effects of angiotensin II (AII), insulin, and IGF-1 on IRS-1-associated PI 3-kinase activity in RASMC. Cells were stimulated with $100 \mathrm{nM}$ AII (7 min), and/or $100 \mathrm{nM}$ insulin (5 min) and IRS-1 immunoprecipitable PI 3-kinase was measured. ( $A$ ) Autoradiography of a representative experiment in triplicate. $P I 3-P$ indicates the migration position of phosphatidylinositol 3-phosphate. Origin indicates the migration origin of PI 3-P. (B) Bar graph shows the relative incorporation of ${ }^{32} \mathrm{P}$ into PI 3-P (mean \pm SEM) from three separate experiments. Significant differences $(* P<0.05$, ANOVA) are indicated. (C) IRS-1-associated PI 3-kinase activity in control cells and after AII (7 min), IGF-1 (5 min), or AII followed by IGF-1. The bar graph shows the relative incorporation of ${ }^{32} \mathrm{P}$ into PI 3-P (mean \pm SEM) from one triplicate experiment. Similar results were obtained in another triplicate experiment. 
A
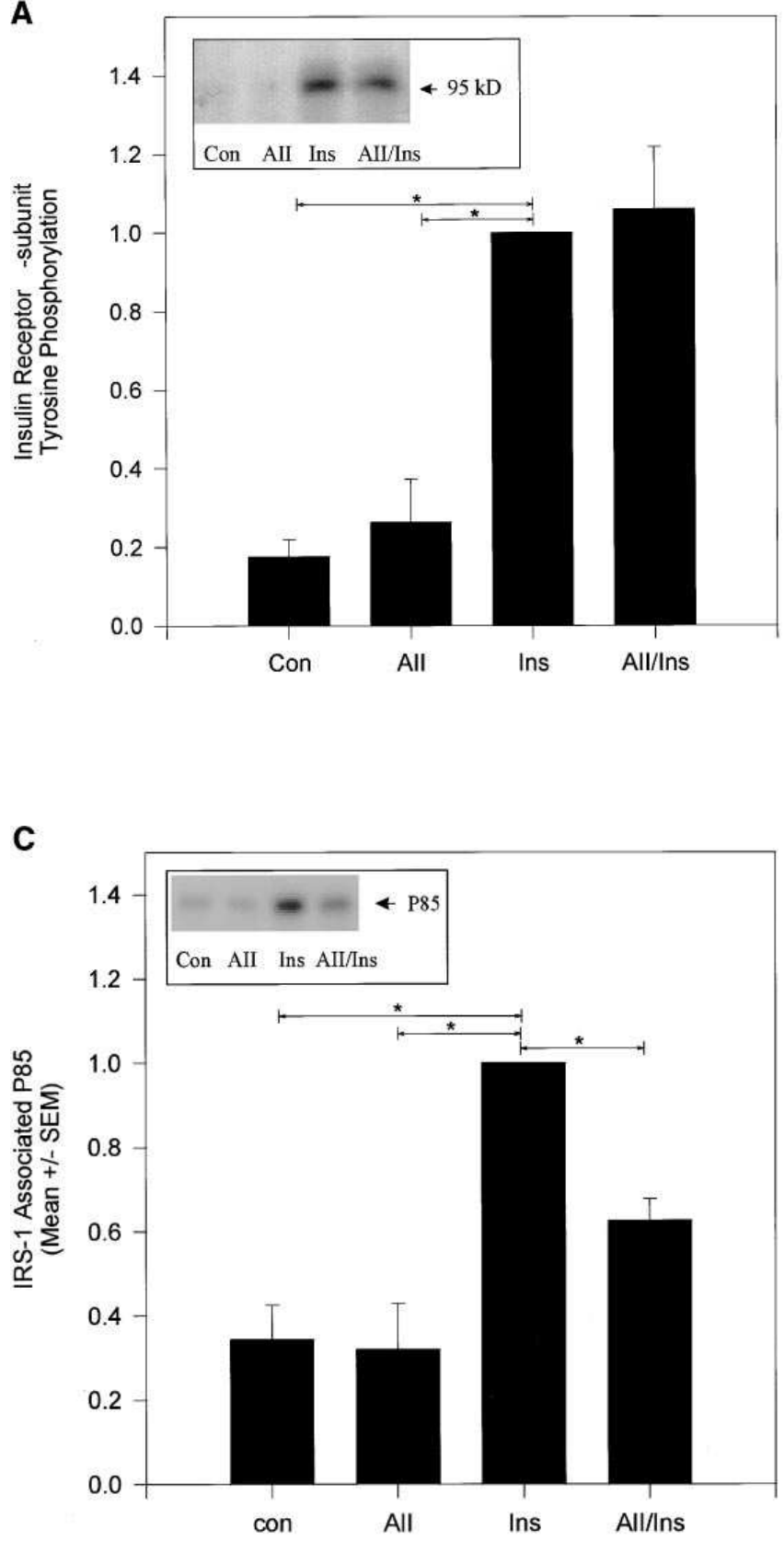

antagonists Sar $^{1}$, Ile $^{8}$-angiotensin (saralasin), losartan, or PD123319 followed by stimulation with the combination AII and insulin. Saralasin, a general AII receptor antagonist, completely blocked the inhibitory effect of AII on insulin-stimulated IRS-1/PI 3-kinase docking (Fig. 3 B). Losartan, a specific $\mathrm{AT}_{1}$ receptor antagonist, and $\mathrm{PD} 123319$, an $\mathrm{AT}_{2}$ antagonist, did not significantly alter this AII action. Similarly, saralasin blocked AII's inhibitory effect on IRS-1 associated PI 3-kinase activity whereas losartan had no significant effect (Fig. $3 C$ ). These results reinforce the concept that reduction of IRS-1-associated PI 3-kinase activity after stimulation with AII was due to a reduction in PI 3-kinase binding to IRS-1 and was mediated via a saralasin-sensitive angiotensin II receptor. Previously, we and others $(23,42)$ have shown that losartan inhibits AII-stimulated PAI-1 expression and MAP kinase activation,
B

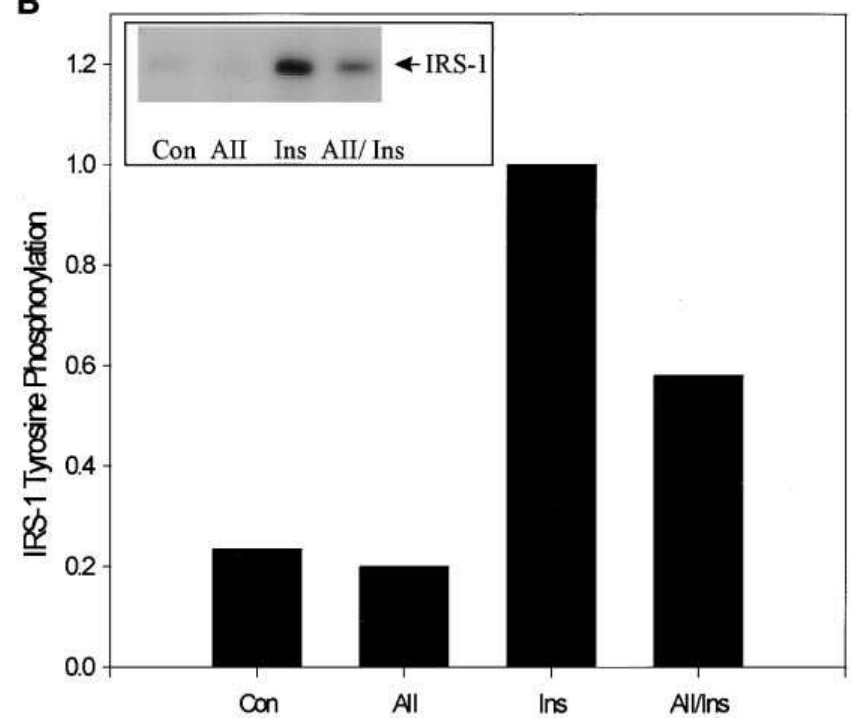

Figure 2. Effect of AII and insulin on insulin receptor autophosphorylation, IRS-1 tyrosine phosphorylation, and p85 binding to IRS-1. RASMC were stimulated as described in Fig. 1. (A) Effect of AII on tyrosine phosphorylation of the insulin receptor $\beta$-subunit. Insulin receptors were immunoprecipitated from wheat germ agglutinin insulin receptor enriched fractions and immunoblotted with $\alpha$-phosphotyrosine antibodies. The inset in the left upper side shows a representative Western blot of phosphotyrosyl-receptor $\beta$-subunit from control cells (Con) and after angiotensin II (AII), insulin (Ins) or AII followed by insulin. The bar graph shows the relative phosphorylation of IR $\beta$-subunit (mean \pm SEM) as determined by PhosphorImager quantitation of four separate experiments. Significant differences $(* P<0.05$, ANOVA) compared with insulin treatment alone are indicated. $(B)$ The inset in the left upper side shows an autoradiograph of a representative Western blot of phosphotyrosyl-IRS-1 from control cells and after AII, insulin (Ins) or AII followed by insulin. The bar graph show the mean of IRS-1 tyrosine phosphorylation from two separate experiments performed in triplicate. $(C)$ p 85 regulatory subunit of PI 3-kinase binding to IRS-1 in control cells (con) and after AII and/or insulin (Ins) stimulation, as described above. P85 associated with IRS-1 immunoprecipitate was measured as described in Methods. Inset shows a representative Western blot of $\mathrm{p} 85$ associated with IRS-1. The bar graph show the relative binding of p85 to IRS-1 (mean \pm SEM) as determined by PhosphorImager quantitation of three separate triplicate experiments. Significant differences $(* P<0.05$, ANOVA) are indicated.

demonstrating the effectiveness of this antagonist on other AII actions in this cell type.

Effects of AII and insulin on insulin receptor $\beta$-subunit and IRS-1 serine phosphorylation. Increased serine phosphorylation of either the $\beta$-subunit of the insulin receptor or IRS- 1 is associated with reduced insulin signaling (43-47). Since AII has been shown to activate serine/threonine kinases, including PKC (20), the effects of AII on the phosphorylation states of both the insulin receptor $\beta$-subunit and IRS- 1 were examined. RASMC were metabolically labeled with $\left[{ }^{32} \mathrm{P}\right]$ orthophosphate, stimulated with AII and/or insulin, and either the insulin receptor or IRS-1 was immunoprecipitated. Analysis of insulin receptor immunoprecipitates revealed that AII increased phosphorylation of the receptor $\beta$-subunit by $70 \%$ (Fig. $4 \mathrm{~A}$ ). Phosphoamino acid analysis showed that the AII-stimulated 
A
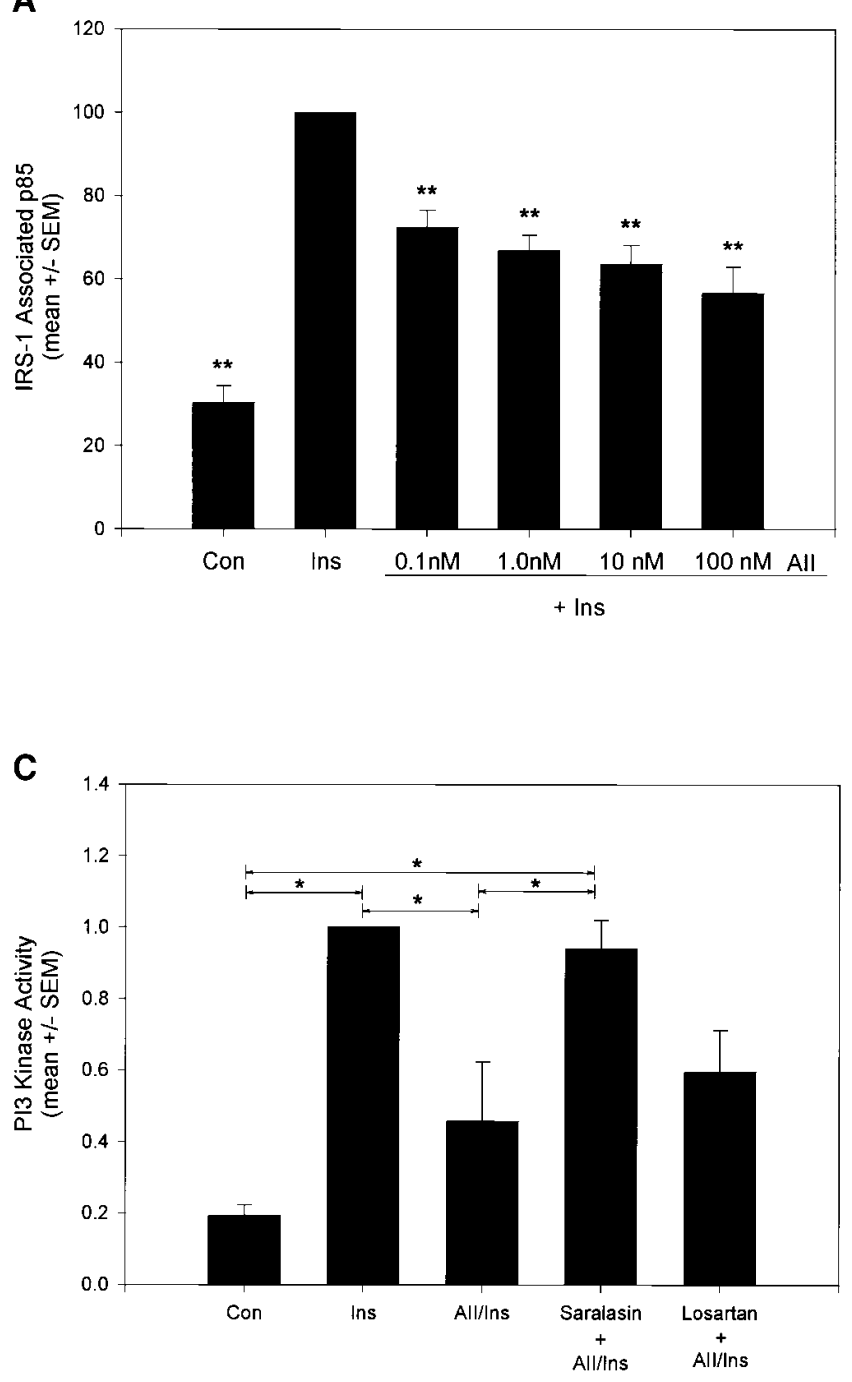

increase in insulin receptor phosphorylation was due to an increase in phosphoserine (Fig. $4 \mathrm{C}$ ). Stimulation of RASMC with AII also increased the phosphorylation of IRS-1 by $75 \%$ (Fig. $4 \mathrm{~B}$ ). Again this phosphorylation was associated with an increase in phosphoserine (Fig. $4 C$ ). Interestingly, the magnitudes of AII-induced increases in total phosphorylation of both the insulin receptor and IRS-1 were similar to that induced by insulin.

The PTB domain of IRS-1 plays a key role in the docking of IRS- 1 to tyrosine 960 in the juxtamembrane region of the insulin receptor $\beta$-subunit that allows for subsequent substrate tyrosine phosphorylation $(31,40,48)$. Thus, it can be hypothesized that serine phosphorylation of the insulin receptor or IRS-1 might influence their ability to interact with each other for subsequent tyrosine phosphorylation events. In order to investigate this hypothesis, a glutathione S-transferase fusion protein containing the PTB domain of IRS-1 (GST-IRS-1PTB) was allowed to interact in vitro with autophosphorylated WGA purified insulin receptors from control RASMC or cells that had been preincubated with AII for $7 \mathrm{~min}$. The insulin receptor bound to GST-IRS-1-PTB was detected by Western
B

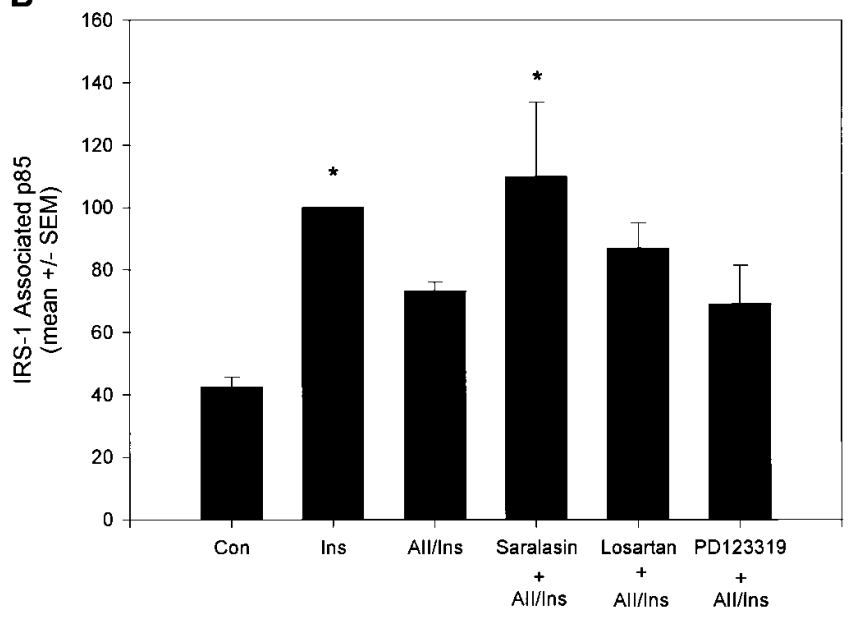

Figure 3. AII dose response and receptor antagonist effects on IRS-1/ PI 3-kinase association. (A) Dose response of AII on insulin-stimulated IRS-1/p85 association. Cells were pretreated with $0.1-100 \mathrm{nM}$ AII for $2 \mathrm{~min}$ followed by a $5 \mathrm{~min}$ stimulation with $100 \mathrm{nM}$ insulin (Ins) as indicated. IRS-1 associated p85 was determined as described in Fig. 2 $C$. Bar graph quantitation on $\mathrm{p} 85$ from three experiments in triplicate is shown. Significant differences ( $* * P<0.01$, ANOVA) compared with insulin stimulation alone are indicated. $(B)$ Effect of AII receptor antagonists of IRS-1/p85 docking. Cells were pretreated for 15 min with AII receptor antagonist saralasin $(1 \mu \mathrm{M}), \mathrm{AT}_{1}$ specific receptor antagonist losartan $(1 \mu \mathrm{M})$, and $\mathrm{AT}_{2}$ antagonist PD123319 $(1 \mu \mathrm{M})$ followed by the stimulation with AII and insulin as described in Fig. $2 C$. IRS-1 was immunoprecipitated and p85 was measured by immunoblotting. Bar graph quantitation from three experiments in triplicate is shown. Significant differences $(* P<0.05$, ANOVA) compared with the control group (Con) are indicated. $(C)$ Effect of AII receptor antagonists on IRS-1-associated PI 3-kinase activity. Cells were pretreated with saralasin and losartan and stimulated with AII and insulin as described above. IRS-1 associated PI 3-kinase activity was measured as described in Fig. 1. Bar graph quantitation of three experiments in triplicate is shown; significant differences $\left({ }^{*} P<0.05\right.$, ANOVA) are indicated. blotting employing anti-insulin receptor antibodies (41). Using this assay, AII did not decrease the ability of the insulin receptor to bind the PTB-domain of IRS-1 (not shown). In another set of experiments, immunopurified IRS-1 from control RASMC or cells treated with AII were incubated with fully autophosphorylated WGA purified insulin receptors from $\mathrm{CHO}$ cells over-expressing the HIR. In this case, AII caused a reduction in the binding of IRS-1 to in vitro tyrosine phosphorylated insulin receptors when compared to control IRS-1 (Fig. 5 ). This suggests that AII-induced modifications of IRS-1, possibly because of serine phosphorylation, decreases IRS-1's ability to associate with the tyrosine phosphorylated $\beta$-subunit of the insulin receptor.

Since AII increased serine phosphorylation correlated with the inhibition of insulin stimulated IRS-1/PI 3-kinase association (Figs. $1 B$ and $2 C$ ), the effect of other agents that may regulate serine phosphorylation were examined. Okadaic acid, a serine/threonine phosphatase inhibitor has been shown to induce a state of postreceptor insulin resistance by inhibiting IRS-1 tyrosine phosphorylation and PI 3-kinase activation in 3T3-L1 adipocytes and 293 cells overexpressing IRS-1 $(43,44)$. 

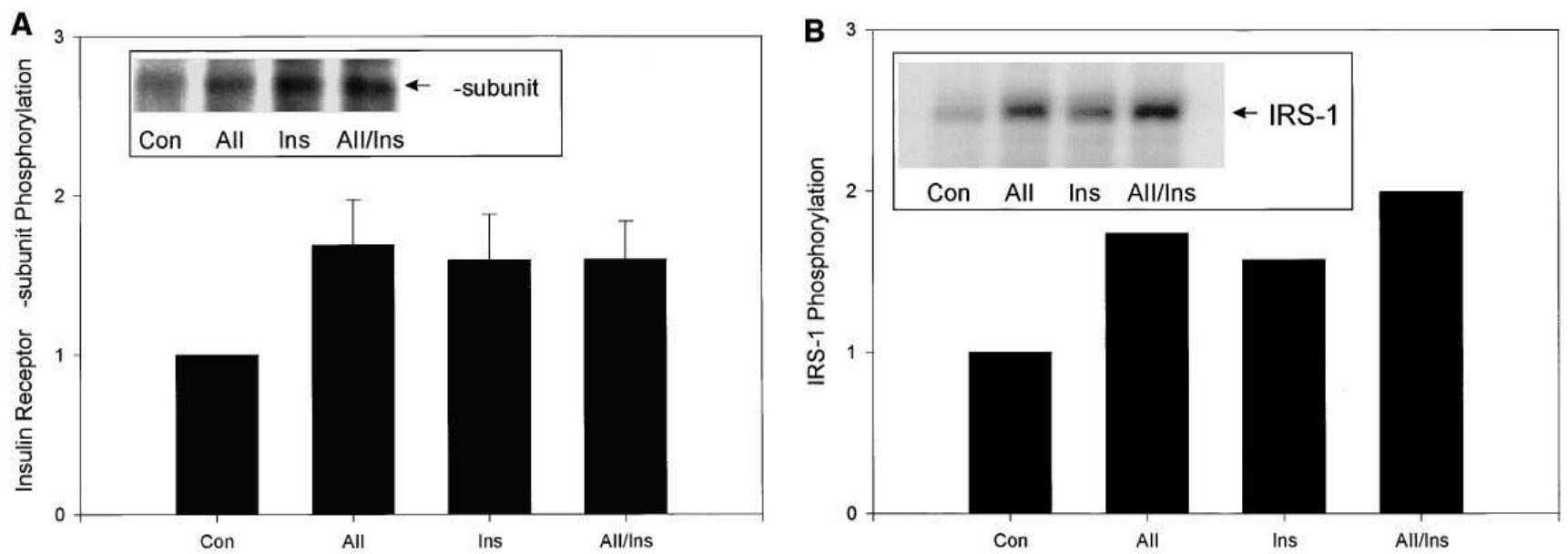

C

Insulin Receptor

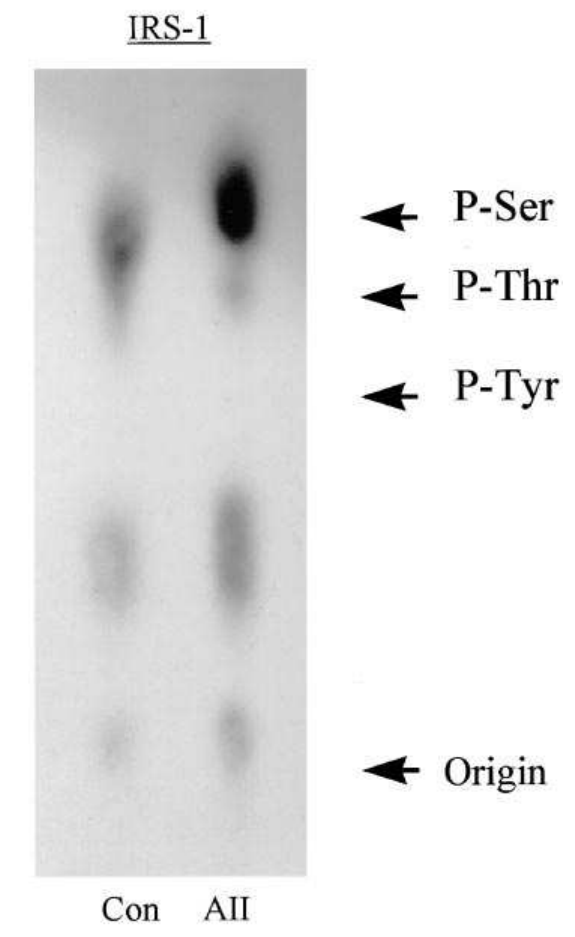

Figure 4. Total phosphorylation and phosphoamino acid analysis of insulin receptor $\beta$-subunit and IRS-1 from metabolically labeled RASMC. Cells were labeled with $\left[{ }^{32} \mathrm{P}\right]$ orthophosphate and stimulated with AII and/or insulin as described in Fig. 1. (A) Immunoprecipitated insulin receptors were separated by SDS-PAGE, and transferred to nitrocellulose. A representative autoradiograph of phosphorylated $\beta$-subunit and bar graph of quantitation (mean \pm SEM) from three experiments are shown. (B) IRS-1 was immunoprecipitated from cells labeled and stimulated as described above. Autoradiograph and bar graph quantitation of total IRS-1 phosphorylation from two experiments is shown. $(C)$ Phosphoamino acid analysis of the insulin receptor and IRS-1 from control and AII-stimulated cells. Phosphoserine $(P$-Ser), phosphothreonine $(P$-Thr), and phosphotyrosine $(P-T y r)$ were separated by thin layer electrophoresis and ${ }^{32} \mathrm{P}$-labeled amino acids were visualized by autoradiography.

In RASMC, okadaic acid (300 nM) inhibited insulin-stimulated IRS- 1 tyrosine phosphorylation and p 85 binding by 30 $40 \%$. These effects of okadaic acid are similar to those produced by AII on insulin signaling (Fig. $6 A$ and data not shown). Altogether these data suggest that AII-mediated inhibition of the early steps of insulin signaling could be at least partially mediated by serine-phosphorylation, as in the case of okadaic acid (this study and reference 43). Pretreatment of cells with $160 \mathrm{nM}$ PMA, to activate PKC also mimicked AII's effect, inhibiting IRS-1-associated PI 3-kinase activity by $40 \%$. However, PKC inhibition, by pretreatment of cells with $10 \mu \mathrm{M}$ bisindolylmaleimide I (GF 109203X) for $15 \mathrm{~min}$, did not block AII's inhibitory effects on IRS-1 associated PI 3-kinase activity (not shown), suggesting that the common $\mathrm{PKC}$ isoforms were not mediating this AII action.

To further investigate potential serine kinases that could be mediating AII's effects on IRS-1, we examined the possibility

of feedback inhibition via PI 3-kinase itself. PI 3-kinase is a dual-specificity kinase (lipid/protein kinase) and activation of its serine kinase has been shown to both stimulate the serine phosphorylation of the p85 regulatory subunit and inhibit the lipid-phosphorylating enzymatic activity of its catalytic subunit $(49,50)$. Since the serine kinase activity of PI 3-kinase has been shown to phosphorylate IRS-1 in vitro $(51,52)$, the effect of PI 3-kinase inhibition on IRS-1/p85 binding was examined. Pretreatment of RASMC with LY294002 increased p85 association with IRS-1 induced by insulin $(P<0.05$, Fig. $6 B)$, an effect similar to that recently reported by Rameh et al. (53). However, PI 3-kinase inhibition did not block AII's ability to reduce p85 association with IRS-1, suggesting that the p85associated serine kinase was not responsible for AII's effect on p85/IRS-1 association (Fig. $6 B$ ).

Effects of AII and PMA on p85 associated PI 3-kinase activity and p85 phosphorylation. While the decrease in IRS-1 


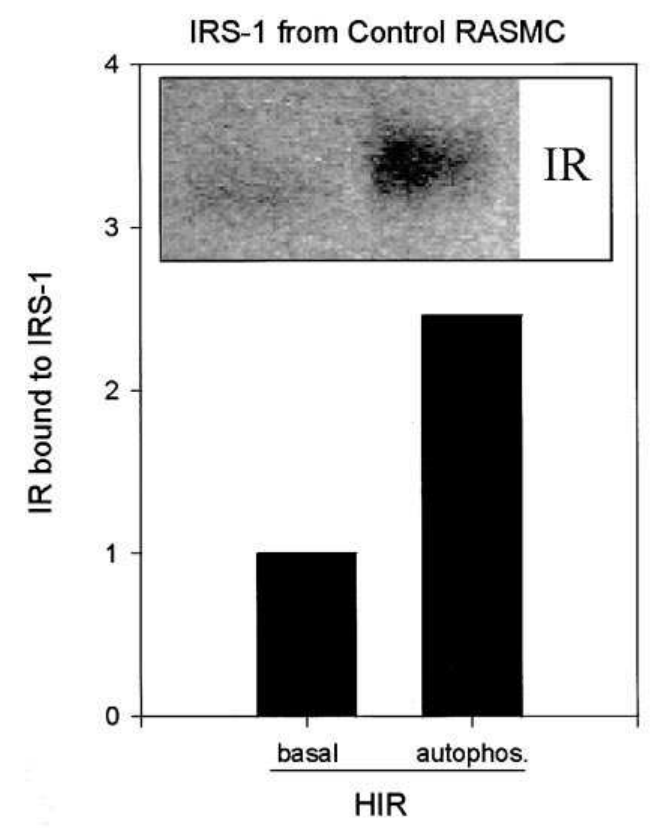

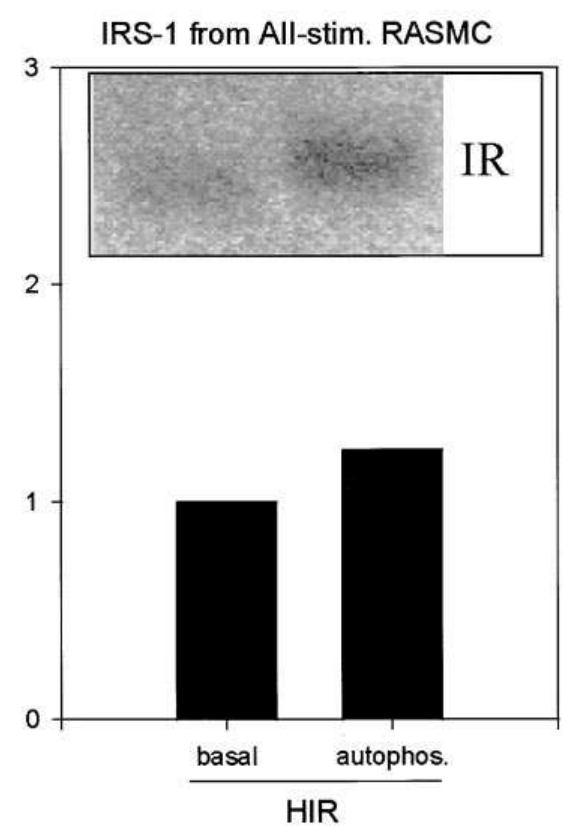

Figure 5. In vitro binding of IRS-1 from control or AII-stimulated RASMC with HIR. IRS-1 was immunoprecipitated from control or AII-stimulated cells and incubated with basal or in vitro autophosphorylated HIR. Precipitates were separated by SDS-PAGE and immunoblotted with antibody against IR $\beta$-subunit followed by ${ }^{125}$ I-labeled protein A. Autoradiography and bar graph quantitation of $\beta$-subunit associated with IRS-1 are shown. associated PI 3-kinase activity in RASMC correlates with a decrease in IRS-1/p85 docking, in vivo studies of AII/insulin crosstalk from cardiac tissue showed that AII could decrease PI 3-kinase activity relative to the amount of p85 associated with IRS-1 (29). To determine whether AII may elicit direct effects on the p85/p110 PI 3-kinase complex, RASMC were stimulated with $100 \mathrm{nM}$ AII for 7 and 15 min or $160 \mathrm{nM}$ PMA for $15 \mathrm{~min}$ and p85 immunoprecipitable PI 3-kinase activity was measured as described in the Methods. Incubation with AII for $7 \mathrm{~min}$ had no effect on the p85 associated PI 3-kinase activity, while prolonged incubation (15 min) with either AII or PMA decreased the p85 pool of PI 3-kinase activity by $35 \%$ $(P<0.05)$ and $42 \%(P<0.05$, ANOVA), respectively (Fig. 7 $A)$. Immunoprecipitation of $\mathrm{p} 85$ from cells incubated with AII or PMA followed by Western blotting with antibodies directed against the p85 and the p110 catalytic subunit of PI 3-kinase demonstrated that the amount of the two proteins was unaltered as compared to the basal condition. An additional protein of 50-55 kD was identified in p85 immunoblots of $\mathrm{p} 85 \mathrm{im}$ munoprecipitates with an intensity of approximately one tenth
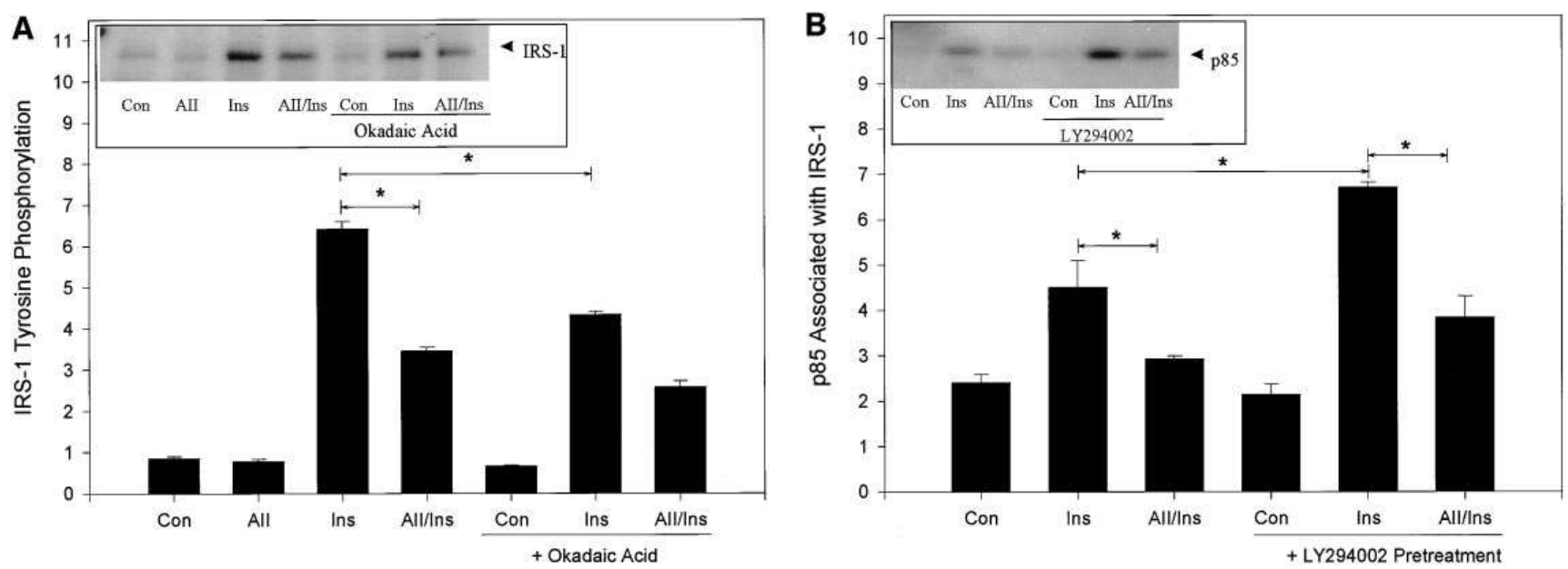

Figure 6. Effect of okadaic acid and PI 3-kinase inhibition on IRS-1 tyrosine phosphorylation and p85 association in RASMC. (A) RASMC were preincubated in the presence or absence of $300 \mathrm{nM}$ okadaic acid for $40 \mathrm{~min}$ (as indicated) and then incubated with no addition (Con), insulin (Ins), or AII followed by insulin as described above. IRS-1 proteins were immunoprecipitated from cleared lysates, separated by SDS-PAGE, transferred to nitrocellulose and revealed by monoclonal antiphosphotyrosine antibodies and ${ }^{125}$ I-protein A. A representative autoradiograph of tyrosine-phosphorylated IRS-1 and bar graph of quantitation (mean \pm SEM) from one experiment performed in triplicate are shown. Significant differences $(* P<0.05$, ANOVA) are indicated. $(B)$ Cells were pretreated with $50 \mu \mathrm{M}$ LY294002 for 15 min and stimulated with insulin and AII as described above. IRS-1 immunoprecipitates were separated by SDS-PAGE and immunoblotted with antibody against p85 followed by ${ }^{125}$ I-labeled protein A. An autoradiograph and bar graph quantitation of one experiment in triplicate are shown. *Significant differences $(P<0.05$, ANOVA $)$. 
A

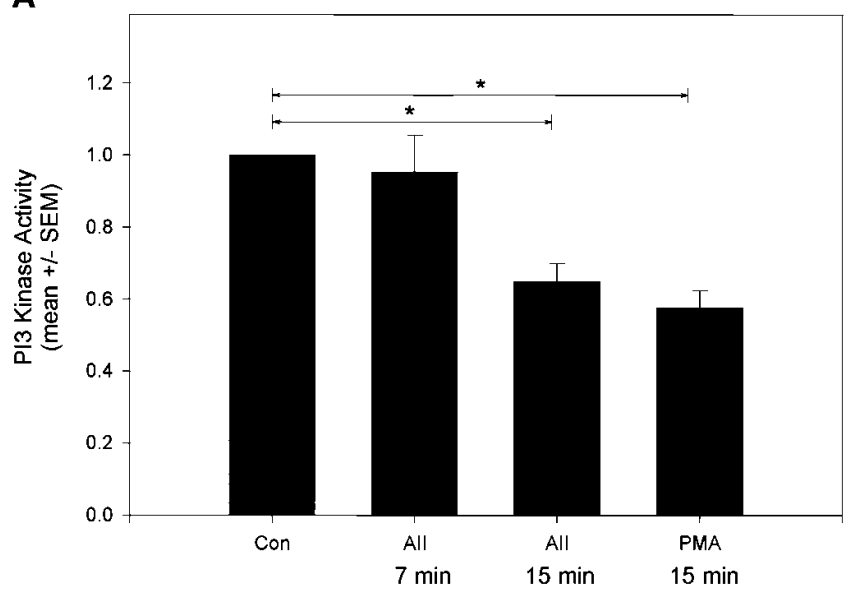

C

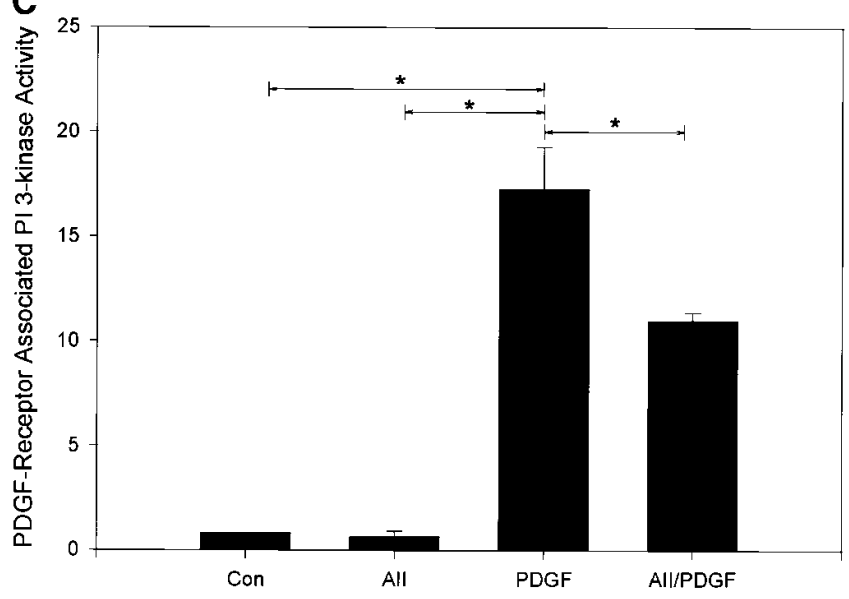

B

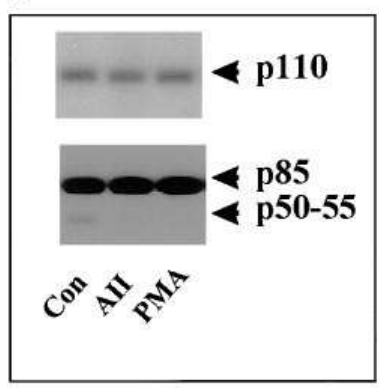

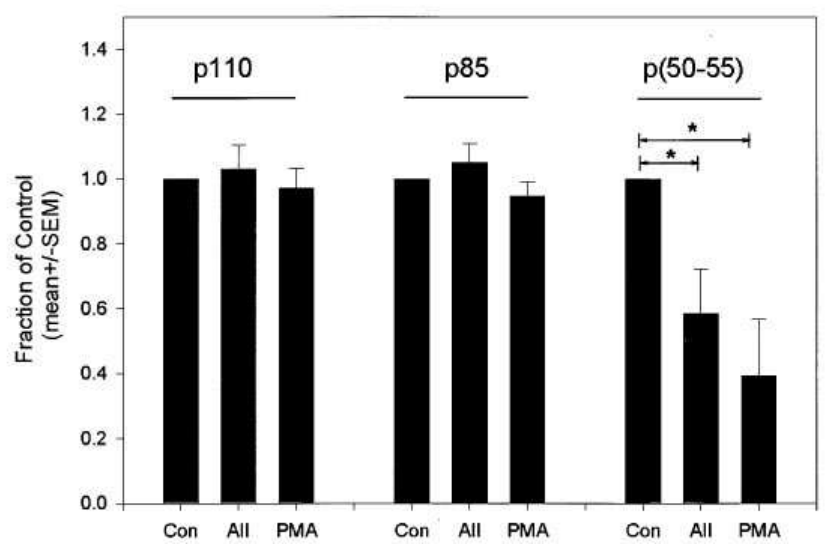

Figure 7. Effects of AII and PMA on p85-associated PI 3-kinase activity. (A) RASMC were incubated with no addition (Con); AII, 7 min; AII, 15 min; and PMA, 15 min. Cell lysates were immunoprecipitated with $\alpha$-p85 antibodies and PI 3-kinase assays performed as described in Methods. The bar graph shows the relative incorporation of ${ }^{32} \mathrm{P}$ into PI 3-P (mean \pm SEM) from four to five separate triplicate experiments. Significant differences $\left({ }^{*} P<0.05\right.$, ANOVA) are indicated. $(B)$ p85 immunoprecipitates from cells treated with AII or PMA for 15 min were separated and immunoblotted with antibody against $\mathrm{p} 85$ or p110. A representative autoradiograph and bar graph quantitation from three experiments in triplicate are shown. $(C)$ PDGF receptor-associated PI 3-kinase activity in RASMC control cells and after AII ( $7 \mathrm{~min}$ ), PDGF (5 min) or AII followed by PDGF. Cell lysates were immunoprecipitated with anti-PDGF receptor antibodies and PI 3-kinase assays were performed as described in Methods. The bar graph shows the relative incorporation of ${ }^{32} \mathrm{P}$ into PI $3-\mathrm{P}($ mean \pm SEM) from one triplicate experiment. Similar results were obtained in another experiment performed in triplicate.

that of p85. Interestingly, the level of this protein was reduced by $50 \%(P<0.05$, ANOVA) after AII or PMA stimulation versus the basal conditions (Fig. $7 \mathrm{~B}$ ). This protein was recognized by antibodies against the entire $\mathrm{p} 85$ sequence, but not by an antibody that recognizes the $\mathrm{SH} 3$ domain of p85, suggesting that these cells express one or more of the alternatively spliced forms of the regulatory subunit of PI 3-kinase that have been described in other cells and tissues and termed p55 $\alpha$ and p85/ AS53 $(54,55)$.

Since these results suggest that AII has an effect on p 85 associated PI 3-kinase above and beyond the effect of docking to IRS-1, we examined the effect of AII on PI 3-kinase coupled to tyrosine phosphorylated PDGF receptor (56). RASMC were stimulated with AII, PDGF, or a combination of the two hormones and PI 3-kinase activity associated with the PDGF receptor was measured as described above. PDGF stimulated a 30-fold increase in the PDGF receptor associated PI 3-kinase activity. While AII alone had no significant effect on the PDGF receptor associated PI 3-kinase activity as compared to control, as with insulin and IGF-1, AII was able to inhibit the
PDGF stimulated PI 3-kinase activity by $30-40 \%(P<0.05$, ANOVA, Fig. $7 C$ ).

To examine the possibility that the inhibitory effects of AII and PMA were related to changes in the phosphorylation state of PI 3-kinase, RASMC were metabolically labeled with $\left[{ }^{32} \mathrm{P}\right]$ orthophosphate, stimulated with AII or PMA, and the p85 subunit of PI 3-kinase was immunoprecipitated and processed for phosphoamino acid analysis. Incubation of cells with AII or PMA increased phosphorylation of the p85 subunit of PI 3 -kinase by 50 and $150 \%$, respectively (Fig. $8 \mathrm{~A}$ ). Phosphoamino acid analysis revealed that the increase in total phosphorylation can be accounted for by an increase in serine phosphorylation (Fig. $8 \mathrm{~B}$ ). A low level of phosphothreonine labeling remained unchanged and no labeling of phosphotyrosine was detected in the basal state or after stimulation with AII or PMA. Thus, AII directly alters PI 3-kinase by decreasing p85 associated PI 3-kinase activity and increasing the serine phosphorylation of $\mathrm{p} 85$. AII also decreases the levels of a $50-55 \mathrm{kD}$ protein which is likely an alternatively spliced form of $\mathrm{p} 85$. 

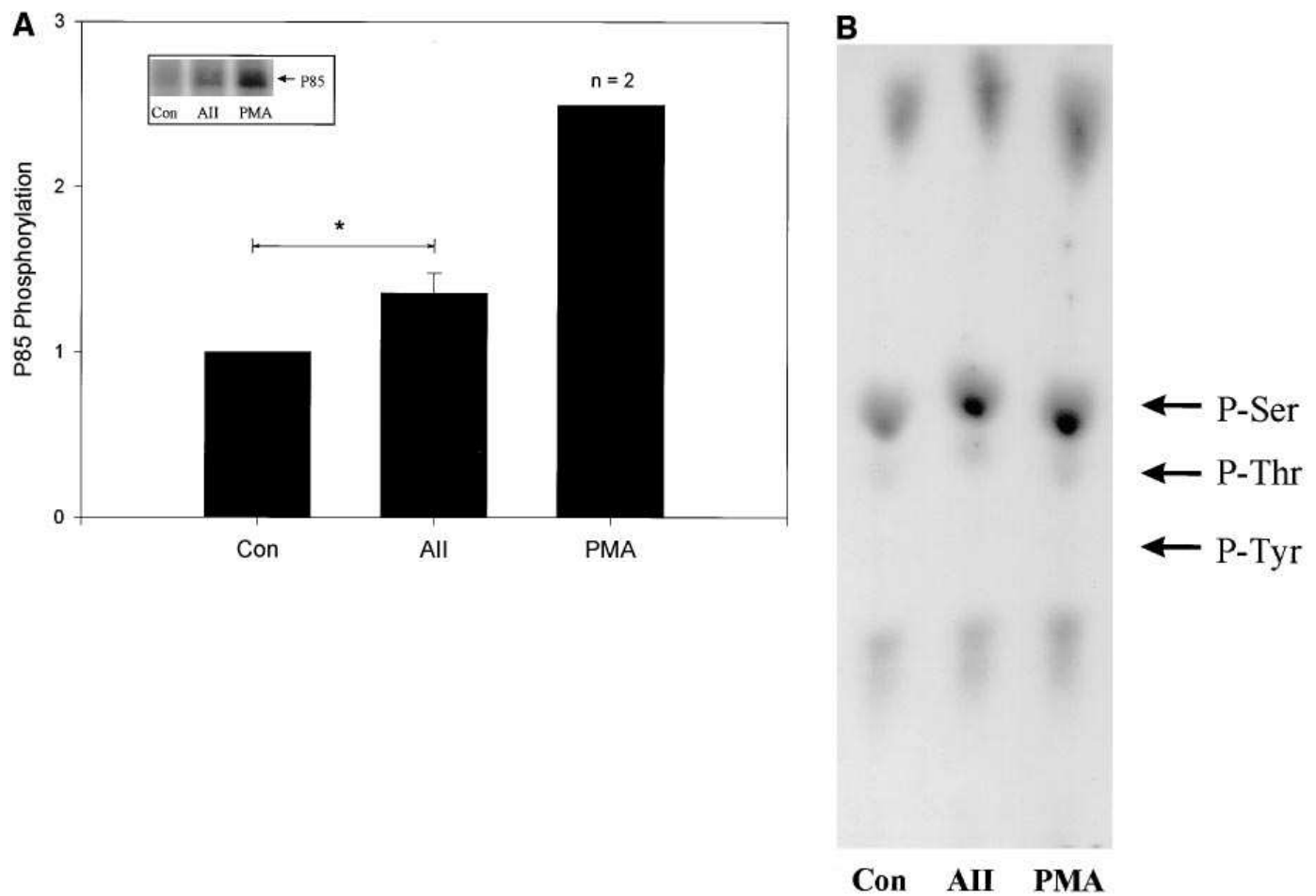

Figure 8. AII stimulates total phosphorylation of the $\mathrm{p} 85$ regulatory subunit of PI 3-kinase.

RASMC were in vivo labeled with [ $\left.{ }^{32} \mathrm{P}\right]$ orthophosphate and the immunoprecipitated p85 proteins were separated by SDS-PAGE, transferred to nitrocellulose, and exposed for autoradiography. The inset shows an autoradiograph of in vivo phosphorylated-p85 regulatory subunit from control cells (Con) and after angiotensin II (AII), or PMA stimulation. The bar graph shows the phosphorylation of p85 regulatory subunit (mean \pm SEM) as determined by PhosphorImager quantitation of two to three separate experiments. The control and AII groups are significantly different $(P<0.05$, Student's $t$ test). $(B)$ Phosphoamino acid analysis of p85 from control, AII (7 min), and PMA (15 min)-stimulated cells was performed as described in Fig. $4 C$.

\section{Discussion}

Intracellular crosstalk between different signaling systems is one of the mechanisms by which cells can integrate multiple hormonal signals for survival and growth. Recent studies have demonstrated that typical $G$ protein-coupled receptors may activate or inhibit the signaling systems classically employed by tyrosine kinase coupled receptors, such as mitogen activated protein kinase, PI 3-kinase, Src, FAK, and JAK2 (21, 22, $57,58)$. This signal integration is particularly important to vascular tissues which are in intimal contact with a variety of circulating hormones. Moreover, a milieu of increased hormone action within the vascular wall, involving the combination of AII, insulin and PDGF, have been strongly implicated in the neointimal formation after balloon injury and atherosclerosis $(9,59,60)$. In this report, we examined the signaling crosstalk between these hormones in cultured aortic smooth muscle cells.

We found that AII inhibited insulin-, IGF-1-, and PDGFtyrosine kinase receptor activation of the PI 3-kinase pathway. Further analysis of AII's effects on the insulin signaling pathway revealed that AII inhibited insulin-stimulated tyrosine phosphorylation of IRS-1 and its corresponding association with the p85 subunit of PI 3-kinase. This occurred via a saralasin-sensitive AII receptor-stimulated pathway that was not blocked by the $\mathrm{AT}_{1}$ isoform antagonist losartan nor the $\mathrm{AT}_{2}$ antagonist PD123319. Previously, we and others have shown that AII-stimulation of plasminogen activator- 1 and -2 expression, and the activation of MAP kinase in these cells are AII signaling pathways which signal via the $\mathrm{AT}_{1}$ receptor $(23,42)$. A role for the $\mathrm{AT}_{2}$ receptor in AII's inhibitory effect on insulin signaling appears unlikely since the $\mathrm{AT}_{2}$ antagonist PD123319 had no effect on IRS-1/p85 association. Since AII's inhibitor effect on IRS-1/p85 docking occurs rapidly, with only a 2 min preincubation, and at low concentrations of AII $(0.1 \mathrm{nM})$, it is unlikely that AII's effects are mediated via biologically active peptides (such as angiotensin III or IV) generated from the limited proteolysis of AII. Therefore, we hypothesize that AII's inhibitory effects on the insulin signaling pathway in these cells are primarily mediated via an AII receptor other than $\mathrm{AT}_{1}$ or $\mathrm{AT}_{2}$.

Recent in vivo studies of AII/insulin crosstalk in rat heart have shown that AII is capable of stimulating tyrosyl-phosphorylation of IRS-1 and IRS-2, docking with PI 3-kinase and inhibition of its enzymatic activity, both in the basal and insulin stimulated states, without affecting tyrosine phosphorylation of IRS- 1 and of the insulin receptor $\beta$-subunit. These latter phenomena could be blocked by $\mathrm{AT}_{1}$ receptor antagonists $(28,29)$. Thus, both in vivo and in vitro studies demonstrate that AII inhibits insulin signaling via the PI 3-kinase pathway, although AII exerts opposite effects on IRS-1 phosphorylation and IRS-1/PI 3-kinase docking in heart and RASMC.

Reduced tyrosyl-phosphorylation as well as increased serine phosphorylation of the $\beta$-subunit of the insulin receptor and IRS-1 have been proposed as mechanisms for the inhibition of insulin signaling $(43-47,61,62)$. In this report, we demonstrate that AII is capable of stimulating serine-phosphorylation of three crucial components of the insulin signaling network, namely the insulin receptor itself, IRS-1 and the p85 subunit of PI 3-kinase (Fig. 9). Pretreatment of cells with AII did not alter insulin receptor autophosphorylation, suggesting that the decrease in IRS-1 tyrosine phosphorylation was not due to a decrease in insulin receptor kinase activity. The effects of AII on IRS- 1 in RASMC, increased IRS- 1 serine 


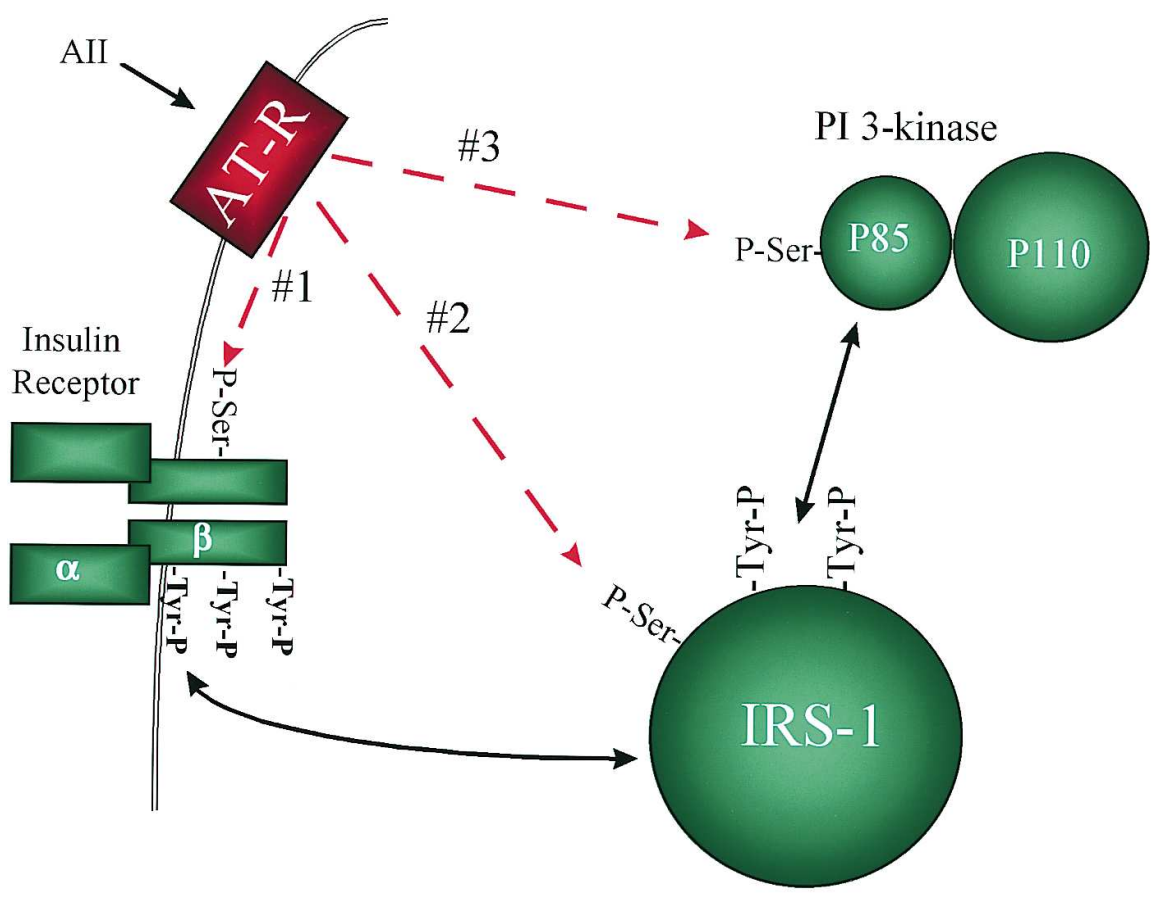

Figure 9. Diagram of AII signaling interactions with the insulin receptor, IRS-1, and PI 3-kinase in RASMC. (Arrow \#1) AII increases serine phosphorylation of the IR. (Arrow \#2) AII inhibits insulin-stimulated tyrosine phosphorylation of IRS-1, increases IRS-1 serine phosphorylation, and inhibits insulin stimulated docking between IRS-1 and PI 3 kinase. (Arrow \#3) AII increases serine phosphorylation of $\mathrm{p} 85$ and decreases the intrinsic PI 3-kinase activity associated with the p85/p110 complex. phosphorylation in association with decreased tyrosine phosphorylation, are reminiscent of those reported with phosphatase $2 \mathrm{~A}$ inhibitor, okadaic acid $(43,44)$. In this study, we also found that okadaic acid as well as phorbol ester mimicked AII's inhibition of PI 3-kinase associated with IRS-1 in RASMC. Since AII increased insulin receptor and IRS-1 serine phosphorylation without impairing the insulin receptor tyrosine kinase, we examined the possibility that AII may inhibit insulin-stimulated IRS-1 tyrosine phosphorylation by reducing IR/IRS-1 association. Consistent with this hypothesis, we found that IRS-1 from AII-stimulated RASMC exhibited a decreased ability to bind autophosphorylated insulin receptor in an in vitro assay. These results suggest that AII can reduce insulin stimulated IRS-1 tyrosine phosphorylation by decreasing the association between the receptor $\beta$-subunit and IRS-1. Thus it is tempting to hypothesize that serine-phosphorylation of IRS-1 impairs its docking to the autophosphorylated insulin receptor. Alternatively, AII may decrease IRS-1/PI 3-kinase association by rapidly inducing the tyrosine dephosphorylation of IRS-1 via the activation or upregulation of a protein-tyrosine phosphatase (63).

While in RASMC the decrease in IRS-1 associated PI $3-$ kinase is in part due to a decrease in IRS-1/p85 docking, in vivo studies of $\mathrm{AII} / \mathrm{insulin}$ crosstalk from cardiac tissue have shown that AII can decrease PI 3-kinase, even in the presence of an increased amount of p85 associated with IRS-1 (29). As these results suggested additional effects of AII on the PI 3-kinase system, the effect of AII on p85 associated PI 3-kinase activity and $\mathrm{p} 85$ phosphorylation was measured. We now find that both AII and phorbol ester significantly reduced the total pool of PI 3-kinase activity associated with p85. The AII- or PMA-stimulated decreases in PI 3-kinase activity could not be explained by decreases in the total amount of immunoprecipitated p85 or p110 subunits, showing that these agonists altered the intrinsic activity rather than the amount of PI 3-kinase. In- terestingly, IRS-1 and PI 3-kinase are also intracellular targets for receptors other than the insulin receptor, such as growth hormone and interferon $\gamma(64)$, suggesting that these inhibitory effects of AII may crosstalk with other receptor pathways. In order to determine if AII could interfere with the coupling of PI 3-kinase to other receptor tyrosine kinase systems, we examined the effect of AII on PDGF-receptor associated PI 3-kinase. Pretreatment of cells with AII decreased PDGFstimulated increases in both PI 3-kinase activity and p85 binding to the PDGF receptor. Since PI 3-kinase autophosphorylation, via a serine kinase intrinsic to the enzyme, has been reported to act as an inhibitory feed back loop on PI 3-kinase activity $(49,50)$, the effect of AII on p85 phosphorylation was measured. These experiments demonstrated that both AII and PMA were capable of increasing serine phosphorylation of p85. To our knowledge this is the first evidence of a hormoneinduced serine phosphorylation and inhibition of the p85/p110 PI 3-kinase. Interestingly, both AII and PMA also decreased the amount of a $\mathrm{p} 85$ isoform in these precipitates with molecular masses of $\sim 50-55 \mathrm{kD}$. This protein(s) was recognized by a polyclonal antibody against the entire p 85 sequence but not by a monoclonal antibody specific to the $\mathrm{SH} 3$ domain of $\mathrm{p} 85$, suggesting that this protein is either the p50 $\alpha$ or AS53 alternatively spliced version of the regulatory protein of PI 3-kinase that has been reported recently $(54,55)$. These results further reinforce the finding that AII can modulate the activity of the PI 3-kinase system.

Since the vasculature is an insulin responsive tissue, AIIinduced insulin resistance in vascular cells may play an important role in the etiology of cardiovascular disease associated with hypertension and noninsulin-dependent diabetes mellitus (NIDDM). The most widely studied insulin actions in the vascular cells and tissue are growth, modulation of gene expression, and the regulation of hemodynamics $(38,39,65)$. Alteration in these actions, mediated via both the insulin receptor 
and IGF-1 receptors, has been proposed to contribute to atherosclerosis and abnormalities in blood flow. While the specific role of insulin-stimulated PI 3-kinase in the vasculature has not yet been established, a recent study suggests that this pathway is important for insulin-stimulated nitric oxide production in endothelial cells (66). Reports from other cell types have shown that activation of PI 3-kinase by growth factors is a crucial step for DNA synthesis and cell division $(67,68)$ and, interestingly, IRS-1 has been shown to be an important requirement for cell cycle progression, cell division, and growth (69-71). Thus, crosstalk between AII and insulin on the IRS-1/ PI 3-kinase pathway may have an important role in the regulation of hemodynamics and vascular growth. The results from this study suggest that AII, and other agents that are able to induce serine phosphorylation of the IR, IRS-1, and/or PI 3-kinase, can contribute to insulin resistance in the vasculature.

\section{Acknowledgments}

This work was supported in part by National Institutes of Health Grants DK 48358 (to E.P. Feener), DK 33201 (to C.R. Kahn), DK 36836 (Joslin's Diabetes and Endocrinology Research Center Grant), and Grants from Istituto Scientifico San Raffaele, Milano, Italy and Ministero della Sanita, Italy (to F. Folli) and the Markey Charitable Trust (E.P. Feener).

\section{References}

1. Dzau, V.J. 1994. Cell biology and genetics of angiotensin in cardiovascular disease. J. Hypertens. 12(suppl):S3-S10.

2. Regitz-Zagrosek, V., M. Neub, and J. Holzmeister. 1996. Molecular biology of angiotensin receptors and their role in human cardiovascular disease. $J$. Mol. Med. 74:233-251.

3. Diet, F., R.E. Pratt, G.J. Berry, N. Momose, G.H. Gibbons, and V.J. Dzau. 1996. Increased accumulation of tissue ACE in human atherosclerotic coronary artery disease. Circulation. 94:2756-2767.

4. Rakugi, H., H.J. Jacob, J.E. Krieger, J.R. Ingelfinger, and R.E. Pratt. 1993. Vascular injury induces angiotensinogen gene expression in the media and neointima. Circulation. 87:283-290.

5. Rakugi, H., D.K. Kim, J.E. Krieger, D.S. Wang, V.J. Dzau, and R.E. Pratt. 1994. Induction of angiotensin converting enzyme in the neointima after vascular injury. Possible role in restenosis. J. Clin. Invest. 93:339-346.

6. Daemen, M.J.A.P., D.M. Lombardi, F.T. Bosman, and S.M. Schwartz. 1991. Angiotensin II induces smooth muscle cell proliferation in the normal and injured rat arterial wall. Circ. Res. 68:450-456.

7. Hamdan, A.D., W.C. Quist, J.B. Gagne, and E.P. Feener. 1996. Angiotensin-converting enzyme inhibition suppresses plasminogen activator inhibitor-1 expression in the neointima of balloon-injured rat aorta. Circulation. 93: 1073-1078.

8. Kim, S., M. Kawamura, H. Wanibuchi, K. Ohta, A. Hamaguchi, T. Omura, T. Yukimura, K. Miura, and H. Iwao. 1995. Angiotensin II type 1 receptor blockade inhibits the expression of immediate-early genes and fibronectin in rat injured artery. Circulation. 92:88-95.

9. Powell, J.S., J.-P. Clozel, R.K.M. Muller, H. Kuhn, F. Hefti, M. Hosang, and H.R. Baumgartner. 1989. Inhibitors of angiotensin converting enzyme prevent myointimal proliferation after vascular injury. Science (Wash. DC). 245: 186-188

10. Garg, R., and S. Yusef. 1995. Overview of randomized trials of angiotensin-converting enzyme inhibitors on mortality and morbidity in patients with heart failure. JAMA (J. Am. Med. Assoc.). 273:1450-1456.

11. MERCATOR Study Group. 1992. Does the new angiotensin-converting-enzyme inhibitor cilazapril prevent restenosis after percutaneous transluminal coronary angioplasty? Results of the MERCATOR study: a multicenter, randomized, double blind placebo-controlled trial. Circulation. 86:100-110.

12. Torlone, E., M. Britta, A.M. Rambotti, G. Perriello, F. Santeusanio, P. Brunetti, and G.B. Bolli. 1993. Improved insulin action and glycemic control after long-term angiotensin-converting enzyme inhibition in subjects with arterial hypertension and type II diabetes. Diabetes Care. 16:1347-1355.

13. Shieh, S., D. Shen, W.H.H. Sheu, M. Fuh, C.Y. Jeng, J.R. Jeng, Y.I. Chen, and G.M. Reaven. 1992. Improvement in metabolic risk factors for coronary heart disease associated with cilazapril treatment. Am. J. Hypertens. 5: 506-510.

14. Raccah, D., M. Pettenuzzo-Mollo, O. Provendier, L. Boucher, J.A. Co- zic, R. Gorlier, P. Huin, J. Sicard, and P. Vague. 1994. Comparison of the effects of captopril and nicardipine on insulin sensitivity and thrombotic profile in patients with hypertension and android obesity. Am. J. Hypertens. 7:731-738.

15. Howard, G., D.H. O'Leary, D. Zaccaro, S. Haffner, M. Rewers, R. Hamman, J.V. Selby, M.F. Saad, P. Savage, R. Bergman, and IRAS Investigators. 1996. Insulin sensitivity and atherosclerosis. Circulation. 93:1809-1817.

16. Haffner, S.M., M.P. Stern, H.P. Hazuda, B.D. Mitchell, and J.K. Patterson. 1990. Cardiovascular risk factors in confirmed prediabetic individuals. JAMA (J. Am. Med. Assoc.). 263:2893-2898.

17. Ferrannini, E., G. Buzzigoli, R. Bonadonna, M.A. Giorico, M. Oleggini, L. Graziadei, R. Pedrinelli, L. Brandi, and S. Bevilacqua. 1987. Insulin resistance in essential hypertension. N. Engl. J. Med. 317:350-357.

18. Zavaroni, I., E. Bonora, M. Pagliara, E. Dall'Aglio, L. Luchetti, G. Buonanno, P.A. Bonati, M. Bergonzani, L. Gnudi, M. Passeri, et al. 1989. Risk factors for coronary artery diease in healthy persons with hyperinsulinemia and normal glucose tolerance. N. Engl. J. Med. 320:702-706.

19. Murphy, T.J., R.W. Alexander, K.K. Griendling, M.S. Runge, and K.E. Bernstein. 1991. Isolation of a cDNA encoding the vascular type-1 angiotensin II receptor. Nature (Lond.). 351:233-236.

20. Dixon, B.S., R.V. Sharma, T. Dickerson, and J. Fortune. 1994. Bradykinin and angiotensin II: activation of protein kinase $\mathrm{C}$ in arterial smooth muscle. Am. J. Physiol. 266:C1406-C1420.

21. Marrero, M.B., B. Schieffer, W.G. Paxton, I. Heerdt, B.C. Berk, P. Delafontaine, and K.E. Bernstein. 1995. Direct stimulation of Jak/STAT pathway by the angiotensin II AT1 receptor. Nature (Lond.). 375:247-250.

22. Schorb, W., T.C. Peeler, N.N. Madigan, K.M. Conrad, and K.M. Baker. 1994. Angiotensin II-induced protein tyrosine phosphorylation in neonatal rat cardiac fibroblasts. J. Biol. Chem. 269:19626-19632.

23. Feener, E.P., J.M. Northrup, L.P. Aiello, and G.L. King. 1995. Angiotensin II induces plasminogen activator inhibitor-1 and -2 expression in vascular endothelial and smooth muscle cells. J. Clin. Invest. 95:1353-1362.

24. Bell, L., D.J. Luthringer, J.A. Madri, and S.L. Warren. 1992. Autocrine angiotensin system regulation of bovine aortic endothelial cell migration and plasminogen activator involves modulation of proto-oncogene pp60c-src expression. J. Clin. Invest. 89:315-320.

25. Weber, H., D.S. Taylor, and C.J. Molloy. 1994. Angiotensin II induces delayed mitogenesis and cellular proliferation in rat aortic smooth muscle cells. J. Clin. Invest. 93:788-798.

26. Daub, H., F.U. Weiss, C. Wallasch, and A. Ullrich. 1996. Role of transactivation of the EGF receptor in signalling by $\mathrm{G}$ protein-coupled receptors. Nature (Lond.). 379:557-560.

27. Linseman, D.A., C.W. Benjamin, and D.A. Jones. 1995. Convergence of angiotensin II and platelet-derived growth factor receptor signaling cascades in vascular smooth muscle cells. J. Biol. Chem. 270:12563-12568.

28. Saad, M.J.A., L.A. Velloso, and C.R.O. Carvalho. 1995. Angiotensin II induces tyrosine phosphorylation of insulin receptor substrate 1 and its association with phosphatidylinositol 3-kinase in rat heart. Biochem. J. 310:741-744.

29. Velloso, L.A., F. Folli, X.J. Sun, M.F. White, M.J.A. Saad, and C.R Kahn. 1996. Cross-talk between the insulin and angiotensin signaling systems. Proc. Natl. Acad. Sci. USA. 93:12490-12495.

30. White, M.F., and C.R. Kahn. 1994. The insulin signaling system. J. Biol. Chem. 269:1-4.

31. Eck, M.J., S. Dhe-Paganon, T. Trub, R.T. Nolte, and S.E. Shoelson. 1996. Structure of the IRS-1 PTB domain bound to the juxtamembrane region of the insulin receptor. Cell. 85:695-705.

32. Sun, X.J., L. Wang, Y. Zhang, L. Yenush, M.G. Myers, Jr., E. Glasheen, W.S. Lane, J.H. Pierce, and M.F. White. 1995. Role of IRS-2 in insulin and cytokine signalling. Nature (Lond.). 377:173-177.

33. Sun, X.J., P. Rotheenberg, C.R. Kahn, J.M. Backer, E. Araki, P.A. Wilden, D.A. Cahill, B.J. Goldstein, and M.F. White. 1991. Structure of the insulin receptor substrate IRS-1 defines a unique signal transduction protein. $\mathrm{Na}$ ture (Lond.). 352:73-77.

34. Folli, F., M.J. Saad, J.M. Backer, and C.R. Kahn. 1992. Insulin stimulation of phosphatidylinositol 3-kinase activity and association with insulin receptor substrate 1 in liver and muscle on the intact rat. J. Biol. Chem. 267:2217122177.

35. Sun, X.J., S. Pons, T. Asano, M.G. Myers, Jr., E. Glasheen, and M.F. White. 1996. The Fyn tyrosine kinase binds IRS-1 and forms a distinct signaling complex during insulin stimulation. J. Biol. Chem. 271:10583-10587.

36. Kelly, K.L., and N.B. Ruderman. 1993. Insulin-stimulated phosphatidylinositol 3-kinase. J. Biol. Chem. 268:4391-4398.

37. Backer, J.M., M.G. Myers, Jr., S.E. Shoelson, D.J. Chin, X.-J. Sun, M. Miralpeix, P. Hu, B. Margolis, E.Y. Skolnik, J. Schlessinger, and M.F. White. 1992. Phosphatidylinositol $3^{\prime}$-kinase is activated by association with IRS-1 during insulin stimulation. EMBO (Eur. Mol. Biol. Organ.) J. 11:3469-3479.

38. Steinberg, H.O., G. Brechtel, A. Johnson, N. Fineberg, and A.D. Baron 1994. Insulin-mediated skeletal muscle vasodilation is nitric oxide dependent. A novel action of insulin to increase nitric oxide release. J. Clin. Invest. 94:11721179 .

39. Scherrer, U., D. Randin, P. Vollenweider, L. Vollenweider, and P. Nicod. 1994. Nitric oxide release accounts for insulin's vascular effects in humans. J. Clin. Invest. 94:2511-2515. 
40. Feener, E.P., J.M. Backer, G.L. King, P.A. Wilden, X.J. Sun, C.R. Kahn, and M.F. White. 1993. Insulin stimulates serine and tyrosine phosphorylation in the juxtamembrane region of the insulin receptor. J. Biol. Chem. 268:1125611264.

41. Wolf, G., T. Trub, E. Ottinger, L. Groninga, A. Lynch, M.F. White, M. Miyazaki, J. Lee, and S.E. Shoelson. 1995. PTB domains of IRS-1 and shc have distinct but overlapping binding specificities. J. Biol. Chem. 270:27407-27410.

42. Eguchi, S., T. Matsumoto, E.D. Motley, H. Utsunomiya, and T. Inagami. 1996. Identification of an essential signaling cascade for mitogen-activated protein kinase activation by angiotensin II in cultured rat vascular smooth muscle cells. J. Biol. Chem. 274:14169-14175.

43. Tanti, J., T. Gremeaux, E. Van Obberghen, and Y. Le Marchand-Brustel. 1994. Serine/threonine phosphorylation of insulin receptor substrate 1 modulates insulin receptor signaling. J. Biol. Chem. 269:6051-6057.

44. Mothe, I., and E. Van Obberghen. 1996. Phosphorylation of insulin receptor substrate- 1 on multiple serine residues, 612, 632, 662, and 731, modulates insulin action. J. Biol. Chem. 271:11222-11227.

45. Takayama, S., M.F. White, and C.R. Kahn. 1988. Phorbol ester-induced serine phosphorylation of the insulin receptor decreases its tyrosine kinase activity. J. Biol. Chem. 263:3440-3447.

46. Hotamisligil, G.S., P. Peraldi, A. Budavari, R. Ellis, M.F. White, and B.M. Spiegelman. 1996. IRS-1-mediated inhibition of insulin receptor tyrosine kinase activity in TNF- $\alpha$ and obesity-induced insulin resistance. Science (Wash. DC). 271:665-668.

47. Pillay, T.S., S. Xiao, and J.M. Olefsky. 1996. Glucose-induced phosphorylation of the insulin receptor. J. Clin. Invest. 97:613-620.

48. White, M.F., J.N. Livingston, J.M. Backer, V. Lauris, T.J. Dull, A. Ullrich, and C.R. Kahn. 1988. Mutation of the insulin receptor at tyrosine 960 inhibits signal transmission but does not affect its tyrosine kinase activity. Cell. 54 : 641-649.

49. Dhand, R., I. Hiles, G. Panayotou, S. Roche, M.J. Fry, I. Gout, N.F. Totty, O. Truong, P. Vicendo, K. Yonezawa, et al. 1994. PI 3-kinase is a dual specificity enzyme: autoregulation by an intrinsic protein-serine kinase activity. EMBO (Eur. Mol. Biol. Organ.) J. 13:522-533.

50. Carpenter, C.L., K.R. Auger, B.C. Duckworth, W.M. Hou, B. Schaffhausen, and L.C. Cantley. 1993. A tightly associated serine/threonine protein kinase regulates phosphoinositide 3-kinase activity. Mol. Cell. Biol. 13:16571665 .

51. Tanti, J., T. Gremeaux, E. Van Obbergen, and Y. Le Marchand-Brustel. 1994. Insulin receptor substrate 1 is phosphorylated by the serine kinase activity of phosphatidylinositol 3-kinase. Biochem. J. 304:17-21.

52. Lam, K., C.L. Carpenter, N.B. Ruderman, J.C. Friel, and K.L. Kelley. 1994. The phosphatidylinositol 3-kinase serine kinase phosphorylates IRS-1. Stimulation by insulin and inhibition by Wortmannin. J. Biol. Chem. 269:2064820652

53. Rameh, L.E., C. Chen, and L.C. Cantley. 1995. Phosphatidylinositol $(3,4,5) \mathrm{P} 3$ interacts with $\mathrm{SH} 2$ domains and modulates PI 3-kinase association with tyrosine-phosphorylated proteins. Cell. 83:821-830.

54. Antonetti, D.A., P. Algenstaedt, and C.R. Kahn. 1996. Insulin receptor substrate 1 binds two novel splice variants of the regulatory subunit of phosphatidylinositol 3-kinase in muscle and brain. Mol. Cell. Biol. 16:2195-2203.

55. Inukai, K., M. Anai, E. Van Breda, T. Hosaka, H. Katagiri, M. Funaki, Y. Fukushima, T. Ogihara, Y. Yazaki, M. Kikuchi, et al. 1996. A novel 55-kDa regulatory subunit for phosphatidylinositol 3-kinase structurally similar to p55PIK is generated by alternative splicing of the p85 $\alpha$ gene. J. Biol. Chem. 271:5317-5320.
56. Klippel, A., J.A. Escobedo, W.J. Fantl, and L.T. Williams. 1992. The C-terminal SH2 domain of p85 accounts for the high affinity and specificity of the binding of phosphatidyinositol 3-kinase to phosphorylated platelet-derived growth factor $\beta$ receptor. Mol. Cell. Biol. 12:1451-1459.

57. Stoyanov, B., S. Volinia, T. Hanck, I. Rubio, M. Loubtchenkov, D. Malek, S. Stoyanova, B. Vanhaesebroeck, R. Dhand, B. Nurnberg, et al. 1995. Cloning and characterization of a $\mathrm{G}$ protein-activated human phosphoinositide-3 kinase. Science (Wash. DC). 269:690-693.

58. Wan, Y., T. Kurosaki, and X.-Y. Huang. 1996. Tyrosine kinases in activation of the MAP kinase cascade by G protein-coupled receptors. Nature (Lond.). 380:541-544.

59. Jawien, A., D.F. Bowen-Pope, V. Lindner, S.M. Schwartz, and A.W. Clowes. 1992. Platelet-derived growth factor promotes smooth muscle migration and intimal thickening in a rat model of balloon angioplasty. J. Clin. Invest. 89:507-511.

60. Ridray, S., D. Heudes, O. Michel, L. Penicaud, and A. Ktorza. 1994. Increased SMC proliferation after endothelial injury in hyperinsulinemic obese Zucker rats. Am. J. Physiol. 267:H1976-H1983.

61. Caro, J.F., O. Ittoop, W.J. Pories, D. Meelheim, E.G. Flickinger, F. Thomas, M. Jenquin, J.F. Silverman, P.G. Khazanie, and M.K. Sinha. 1986. Studies on the mechanism of insulin resistance in the liver from humans with noninsulin-dependent diabetes. Insulin action and binding in isolated hepatocytes, insulin receptor structure, and kinase activity. J. Clin. Invest. 78:249-258.

62. Folli, F., M.J. Saad, J.M. Backer, and C.R. Kahn. 1993. Regulation of the phosphatidylinositol 3-kinase activity in liver and muscle of animal models of insulin-resistant and insulin-deficient diabetes mellitus. J. Clin. Invest. 92: 1787-1794.

63. Duff, J.L., M.B. Marrero, W.G. Paxton, C.H. Charles, L.F. Lau, K.E. Bernstein, and B.C. Berk. 1993. Angiotensin II induces 3CH134, a proteintyrosine phosphatase, in vascular smooth muscle cells. J. Biol. Chem. 268 26037-26040.

64. Myers, M.G., Jr., and M.F. White. 1996. Insulin signal transduction and the IRS proteins. Annu. Rev. Pharmacol. Toxicol. 36:615-658.

65. Banskota, N.K., R. Taub, K. Zellner, P. Olsen, and G.L. King. 1989. Characterization of the induction of proto-oncogene c-myc and cellular growth in human vascular smooth muscle cells by insulin and IGF-1. Diabetes. 38:123129.

66. Zeng, G., and M.J. Quon. 1996. Insulin-stimulated production of nitric oxide is inhibited by wortmannin. J. Clin. Invest. 98:894-898.

67. Cheatham, B., C.J. Vlahos, L. Cheatham, L. Wang, J. Blenis, and C.R. Kahn. 1994. Phosphatidylinositol 3-kinase activation is required for insulin stimulation of pp70 S6 kinase, DNA synthesis, and glucose transporter translocation. Mol. Cell. Biol. 14:4902-4911.

68. Chung, J., T.C. Grammer, K.P. Lemon, A. Kazlauskas, and J. Blenis. 1994. PDGF- and insulin-dependent pp70S6k activation mediated by phosphatidylinositol-3-OH kinase. Nature (Lond.). 370:71-75.

69. Araki, E., M.A. Lipes, M.E. Patti, J.C. Bruning, B. Haag 3rd, R.S. Johnson, and C.R. Kahn. 1994. Alternative pathway of insulin signalling in mice with targeted disruption of the IRS-1 gene. Nature (Lond.). 372:186-190.

70. Tamemoto, H., T. Kadowaki, K. Tobe, T. Yagi, H. Sakura, et al. 1994. Insulin resistance and growth retardation in mice lacking insulin receptor substrate-1. Nature (Lond.). 372:182-186.

71. Rose, D.W., A.R. Saltiel, M. Majumdar, S.J. Decker, J.M. Olefsky. 1994. Insulin receptor substrate-1 is required for insulin mediated mitogenesis signal transduction. Proc. Natl. Acad. Sci. USA. 91:797-801. 